\title{
CHARACTERIZATION OF CYTOCHROME B FROM EUROPEAN FIELD ISOLATES OF CERCOSPORA BETICOLA WITH QUINONE OUTSIDE INHIBITOR RESISTANCE
}

\author{
A Thesis \\ Submitted to the Graduate Faculty \\ of the \\ North Dakota State University \\ of Agriculture and Applied Science
}

\author{
By \\ Keshav Birla \\ In Partial Fulfillment of the Requirements \\ for the Degree of \\ MASTER OF SCIENCE
}

Major Department:

Plant Pathology

November 2012

Fargo, North Dakota 


\section{North Dakota State University \\ Graduate School}

\section{Title}

CHARACTERIZATION OF CYTOCHROME B FROM EUROPEAN FIELD ISOLATES

OF CERCOSPORA BETICOLA WITH QUINONE OUTSIDE INHIBITOR RESISTANCE

By

KESHAV BIRLA

The Supervisory Committee certifies that this disquisition complies with North Dakota State University's regulations and meets the accepted standards for the degree of

\section{MASTER OF SCIENCE}

SUPERVISORY COMMITTEE:

Dr. Gary Secor (Plant Pathology)

Chair

Dr. Melvin Bolton (USDA/Plant Pathology)

Dr. Mohamed Khan (Plant Pathology)

Dr. Eugene Berry (Veterinary \& Microbiological Sciences)

Approved:

$\frac{11 / 01 / 2012}{\text { Date }}$

$\frac{\text { Dr. Jack Rasmussen }}{\text { Department Chair }}$




\begin{abstract}
Cercospora leaf spot (CLS), caused by the fungal pathogen Cercospora beticola, is the most important foliar disease of sugar beet worldwide. Control strategies for CLS rely heavily on fungicides including quinone outside inhibitor $\left(\mathrm{Q}_{\mathrm{O}} \mathrm{I}\right)$ fungicides. We collected 866 C. beticola isolates from sugar beet growing regions in France and Italy and assessed their sensitivity to the $\mathrm{Q}_{\mathrm{O}} \mathrm{I}$ fungicide pyraclostrobin. To gain an understanding of the molecular basis of $\mathrm{Q}_{\mathrm{O}} \mathrm{I}$ resistance, we cloned the full-length coding region of Cbcytb. All tested $\mathrm{Q}_{\mathrm{O}} \mathrm{I}-$-resistant isolates harbored a point mutation in $C b c y t b$ at nucleotide position 428 that conferred an exchange from glycine to alanine at amino acid position 143 (G143A). A PCR assay was developed to discriminate $\mathrm{Q}_{\mathrm{O}} \mathrm{I}-$ sensitive and QoI-resistant isolates based on the G143A mutation. Our results indicate that $\mathrm{Q}_{\mathrm{O}} \mathrm{I}$ resistance has developed in some European $C$. beticola populations in Italy and monitoring the G143A mutation is an essential fungicide resistance management strategy.
\end{abstract}




\section{ACKNOWLEDGEMENTS}

I want to present my deepest thanks to my research adviser Dr. Melvin D. Bolton and academic adviser Dr. Gary Secor, for their guidance and support throughout my graduate study research and during the preparation of this dissertation. I would also like to express my gratitude to my other committee members Dr. Mohamed Khan and Dr. Eugene Berry for their guidance and help to finish my dissertation.

I would also like to thank Viviana Rivera-Varas for her work towards this study and without whom this study would not have been possible. I also want to thank my lab mates, Xiaoyun Wang and Kurt Rudolph, for their guidance and assistance in several of my laboratory techniques and experiments.

Most importantly, I am indebted to my family for their unconditional love, encouragement, and support. Lastly, I would like to thank God for making everything smooth and possible for me. 


\section{TABLE OF CONTENTS}

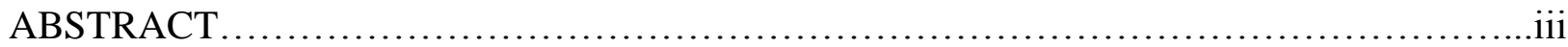

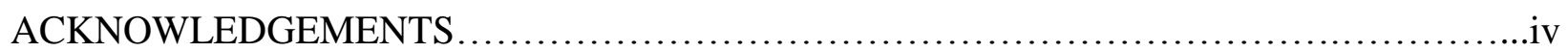

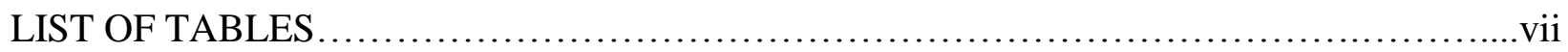

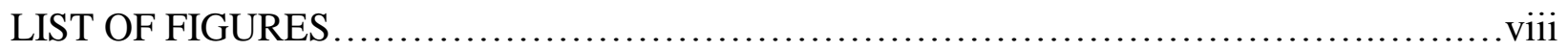

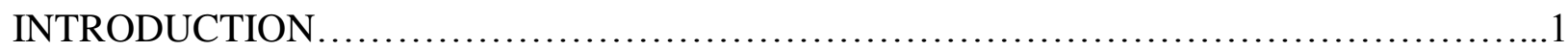

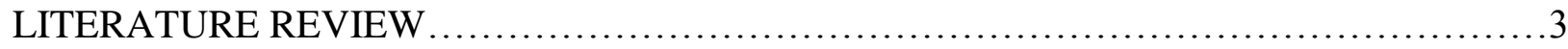

Background of Sugar Beet: The Host....................................................

Cercospora Leaf Spot of Sugar Beet: The Disease....................................... 4

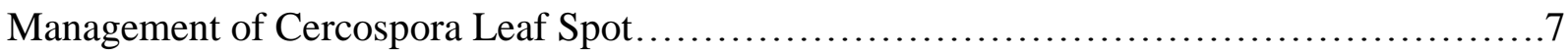

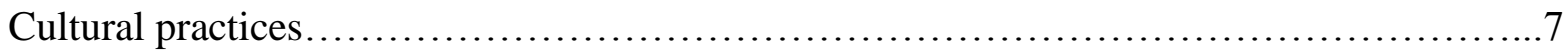

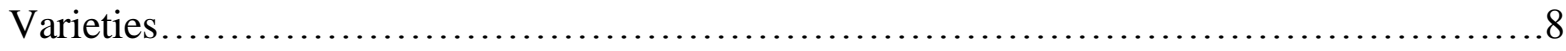

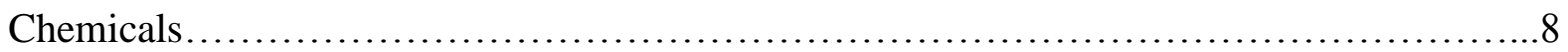

Fungicide Resistance.............................................................. 10

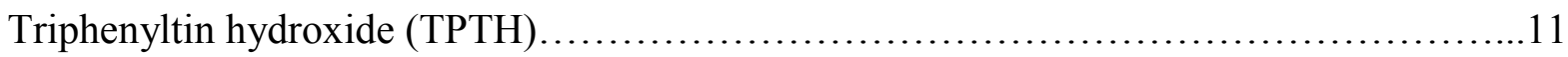

Demethylation inhibitor (DMI) fungicides .......................................... 11

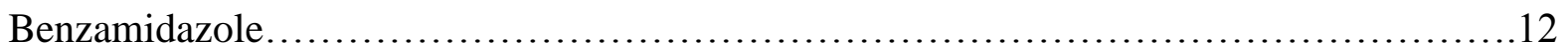

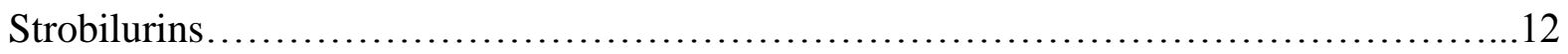

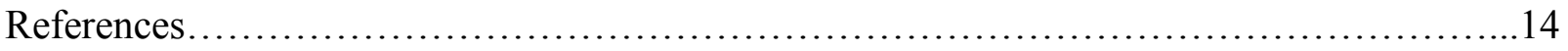

PAPER: CHARACTERIZATION OF CYTOCHROME B FROM EUROPEAN FIELD ISOLATES OF CERCOSPORA BETICOLA WITH QUINONE OUTSIDE INHIBITOR

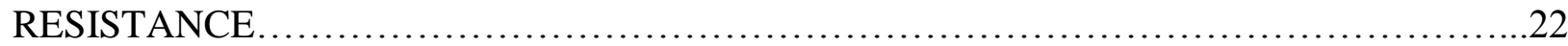

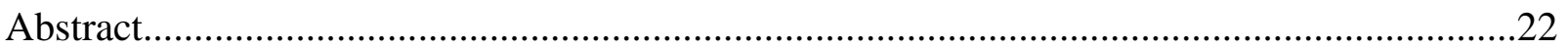

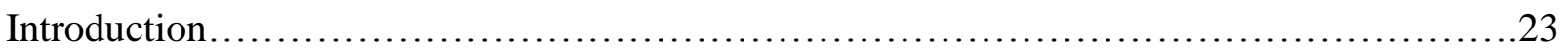

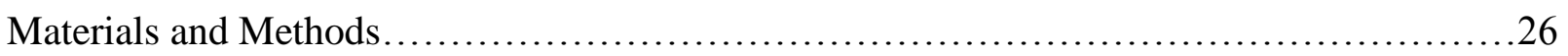


Sample collection and fungal isolation.......................................... 26

Fungicide sensitivity assays and statistical analysis............................... 26

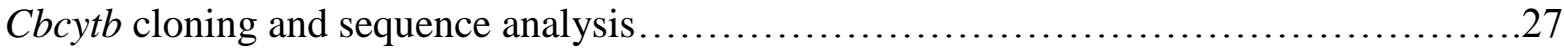

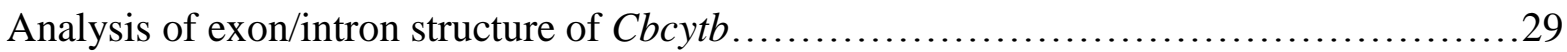

Microsatellite analysis of selected $\mathrm{Q}_{\mathrm{O}} \mathrm{I}-\mathrm{sensitive} \mathrm{and} \mathrm{-resistant} \mathrm{isolates....................31}$

Development of PCR primers to discriminate $\mathrm{Q}_{\mathrm{O}} \mathrm{I}-$ resistant and $\mathrm{Q}_{\mathrm{O}} \mathrm{I}$-sensitive isolates......32

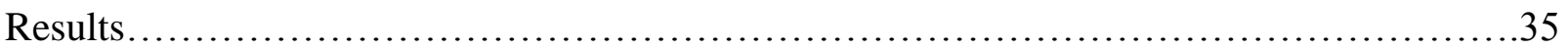

Survey of European Cercospora beticola isolate sensitivity of pyraclostrobin...............35

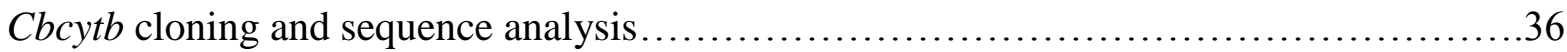

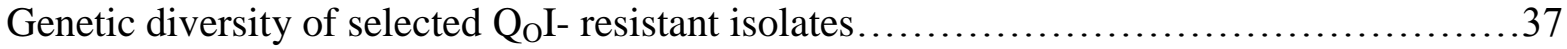

Molecular discrimination of $\mathrm{Q}_{\mathrm{O}} \mathrm{I}-$ sensitive and -resistant isolates........................37

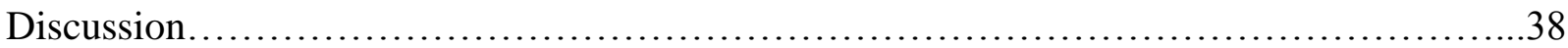

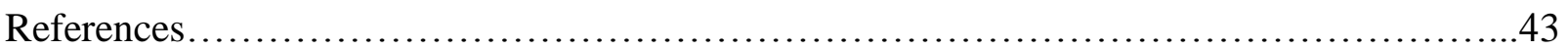




\section{LIST OF TABLES}

Table

$\underline{\text { Page }}$

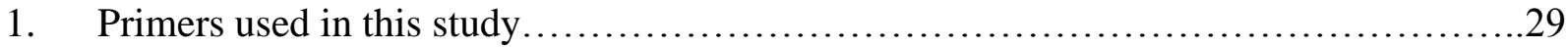

2. Sensitivity of French and Italian Cercospora beticola populations to pyraclostrobin.....30

3. Sub-set of Cercospora beticola isolates used in this study.... .33 


\section{LIST OF FIGURES}

$\underline{\text { Figure }}$

$\underline{\text { Page }}$

1. Symptoms of Cercospora Leaf Spot of sugar beet...............................6

2. Conidia and pseudostromata of Cercospora beticola.......................................6

3. Identification of Cercospora beticola isolates with $\mathrm{Q}_{\mathrm{O}} \mathrm{I}$ resistance.......................... 


\section{INTRODUCTION}

Leaf spot, caused by the hemibiotrophic fungus Cercospora beticola (Sacc.), is the most destructive foliar disease on sugar beet (Beta vulgaris L.) worldwide. C. beticola is able to overwinter as stromata in infected sugar beet leaf residue on or directly below the soil surface (Khan et al, 2008). Sporulation can occur from overwintered stromata and the resulting conidia are delivered to sugar beet leaf surfaces primarily by wind and water splash. The fungus penetrates stomata to gain access to the apoplast (Steinkamp et al, 1979), where effectors are produced by the invading hyphae that facilitate disease establishment and cause necrosis. Conidia produced in necrotic tissue can initiate another disease cycle provided environmental conditions are favorable. Control measures for leaf spot include planting tolerant varieties and crop rotation, but the disease is managed effectively only when combined with timely fungicide applications (Khan et al, 2007; Secor et al, 2010).

An important group of fungicides used to manage Cercospora leaf spot is the strobilurins or quinone outside inhibitors ( $\left.\mathrm{Q}_{\mathrm{O}} \mathrm{Is}\right)$. These fungicides act by binding to the quinol oxidation site of the cytochrome $\mathrm{bc}_{1}$ complex. This binding blocks the transfer of electrons between cytochrome $\mathrm{b}$ to cytochrome $\mathrm{c}_{1}$ complex, thereby, disrupting ATP production by the fungal cells that results in an energy deficit in sensitive fungi. Cytochrome $b$ is a membrane protein that forms the core of the mitochondrial $b_{1}$ complex and is encoded by the cytochrome $b$ (cytb) gene (Bartlett et al, 2002). Resistance to QoIs has been associated with point mutation at the cytb gene. The target mutations F129L, G137R, and G143A appear to play a central role in the mechanism for $\mathrm{Q}_{\mathrm{O}} \mathrm{I}$ resistance (Fisher and Meunier, 2008). G143A is observed in most resistant

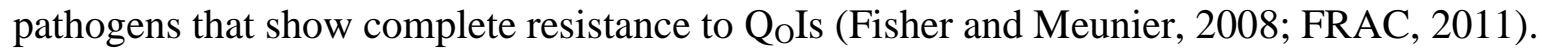


Molecular techniques exploiting point mutations associated with fungicide resistance have been described for several pathosystems (Pasche et al, 2005; Sierotzki et al, 2007). Such techniques allow for rapid, accurate, and reliable detection of fungicide resistance.

Resistance to $\mathrm{Q}_{0} \mathrm{Is}$ by fungal pathogen is predicted to appear early within a few seasons of spray because of their site-specific mode of action. Moreover, C. beticola possess high genetic variability, abundant sporulation, and polycyclic nature that would contribute to $\mathrm{Q}_{\mathrm{O}} \mathrm{I}$ resistance. Despite these risks, until this study, there have been no previous reports of European C. beticola field isolates with resistance to QoIs to date (Karaoglanidis and Ioannidis 2010; Malandrakis et al, 2011). Nonetheless, a current survey of $\mathrm{Q}_{\mathrm{O}} \mathrm{I}$ sensitivity in C. beticola field isolates is important for fungicide resistance management programs. Although sugar beet growers have depended on $Q_{O} I s$ for disease control for more than a decade, a comprehensive survey of $Q_{O} I$ sensitivity has not occurred in the French and Italian sugar beet growing regions. Therefore, the objectives of this study were to (i) determine pyraclostrobin $\mathrm{EC}_{50}$ values of $C$. beticola isolates collected from sugar beet growing regions of France and Italy, (ii) clone the full-length $C$. beticola $c y t b(C b c y t b)$ coding sequence, (iii) sequence Cbcytb from $\mathrm{Q}_{\mathrm{O}} \mathrm{I}-$-resistant and $\mathrm{Q}_{\mathrm{O}} \mathrm{I}-$ sensitive isolates to assess whether any mutations correlate with $\mathrm{Q}_{\mathrm{O}} \mathrm{I}$ resistance, and if a mutation in Cbcytb correlates with QoI-resistance, (iv) develop allele-specific primers that can be used for the detection of $\mathrm{Q}_{\mathrm{O}} \mathrm{I}-$ resistant isolates. 


\section{LITERATURE REVIEW}

\section{Background of Sugar Beet: The Host}

Sugar beet (Beta vulagrisL.) is a member of the beet genus and is classified in the family Chenopodiaceae (Gill and Vear, 1980). The Middle East was the origin of conventional beet species. Different varieties of the sugar beet plant were cultivated on the shores of the Mediterranean since the first century BC (De Rougemont, 1989). The sugar beet was recognized as a plant with valuable sweetening properties during the mid-1700s in Europe. The development of beet into an industrial crop for sugar was possible only after the second half of the eighteenth century with the advancements of technology and industries (Winner, 1993). Since its origin in central Europe in the early part of the nineteenth century, sugar beet cultivation has spread to all populated continents except Australia. Most sugar beet is grown in the temperate regions of Europe, Asia, North America and North Africa (Cooke and Scott, 1993). With the advancement of using sugar beet as a sugar source, first successful sugar beet-based sugar factory in the United States was built at Alvarado, California in 1870 (Coons, 1949).

Sugar beet is one of two crops, the other being sugar cane, which constitute the only important sources of sucrose. Approximately $80 \%$ of all sugar in sugar beet is in the sucrose

form. However, sugar beet is also used for a source of molasses (Ulber et al, 2000) and animal feed. Sugar beet is a product with sweetening and preserving properties that make it a major component of, or additive to, a vast range of foods and beverages (Cooke and Scott, 1993). It is also used as a carbon source for yeast production and as a precursor for chemical and pharmaceutical production (Atiyeh and Duvnjak, 2002). 
Of the current world production of more than 130 million metric tons of sugar, about $35 \%$ is obtained from sugar beet. In the U.S., about $50-55 \%$ of the domestic production of sugar is derived from sugar beet (Harveson et al, 2009). On an average, 1,253,817 acres of land is cultivated for sugar beet every year in the United States with an annual production of 27 million metric tons, which is the second largest after France which produces 35.2 million metric tons of sugar beet each year (UN Food and Agriculture Organization statistics, 2010).

The Red River Valley region of western Minnesota and eastern North Dakota together constitutes $55 \%$ of total planted U.S. sugar beet acreage and is the largest sugar beet producing region in the States (USDA-ARS Statistical Service, 2009). Sugar beet is grown from plantings made in spring and harvested in the fall. Today 11 states and two provinces within four diverse regions are involved with sugar beet production in North America. Other states with major sugar beet production areas include California, Colorado, Idaho, Michigan, Montana, Nebraska, Texas and Wyoming (Harveson et al, 2009).

\section{Cercospora Leaf Spot of Sugar Beet: The Disease}

Cercospora Leaf Spot (CLS) of sugar beet is the most destructive foliar disease of sugar beet worldwide. Loss of sugar occurs when new leaves grow to replace those which are heavily damaged by CLS (Vereijseen et al, 2003). Losses are manifested as a reduced tonnage, reduced sucrose and increased impurities (Lamey et al, 1996).CLS can cause a reduction in gross sugar yield of up to $42 \%$ (Shane and Teng, 1992).

CLS is caused by the hemibiotrophic dothideomycete fungus, Cercospora beticola (Sacc.), which belongs to the phylum Ascomycota. C. beticola infects species of the genus Beta, 
and a number of species in the Chenopodiaceae, including members of the genera Spinacea, Atriplex, Carthamus and Amaranthus (Weiland and Koch, 2004).

The optimal temperature for sporulation, germination of conidia, and host infection by $C$. beticola is observed between 25 to $35^{\circ} \mathrm{C}$. An exposure to high relative humidity (> $90 \%$ ) or free moisture on leaf surface for 5-8 hours also contributes to disease severity.

Infection and lesion formation typically appear first on older leaves followed by progressive appearance on younger leaves (Jacobsen and Franc, 2009). Lesions at maturity are 0.2-0.5 cm in diameter and appear light gray-colored to dark tan with a brown to purple border (Fig. 1). A diagnostic feature of $C$. beticola infection is the presence of tiny black dots (pseudostromata) that can be observed in leaf substomatal cavities within the grayish-tan lesions. Pseudostromata are masses of vegetative hyphae that incorporate host tissue within a sclerotiumlike survival structure. Under high humidity, lesion centers may develop a blue or grayish hue as conidiophores and conidia are produced on pseudostroma (Harveson, 2007). C. beticola produces hyaline to pale olivaceous brown intercellular hyphae which are septate, $2-4 \mu \mathrm{m}$ in diameter, and 50-200 $\mu \mathrm{m}$ long (Weiland et al, 2004) (Fig. 2).

At the time of infection, many important fungal plant pathogens, including C. beticola produce low-molecular weight effectors like cercosporin in the host plant, which kill host tissue as the fungus grows (Daub et al, 2005). Cercosporin is red in color and plays an important role in CLS disease development. Cercosporin is active only when exposed to light. Once cercosporin is activated, it reacts with oxygen and results in the generation of toxic activated oxygen species such as singlet oxygen $\left({ }^{1} \mathrm{O}_{2}\right)$ and superoxide $\left(\mathrm{O}_{2}{ }^{-}\right)$(Daub and Chung, 2007). The toxicity of cercosporin is due to oxidative damage to lipids, proteins, and nucleic acids, with the cellular 
target dependent on where the toxin molecule localizes in cells. It has also been hypothesized that the membrane damage followed by the activity of cercosporin allows for leakage of nutrients into the leaf intercellular spaces that might allow for fungal growth and sporulation (Daub and Chung, 2007).

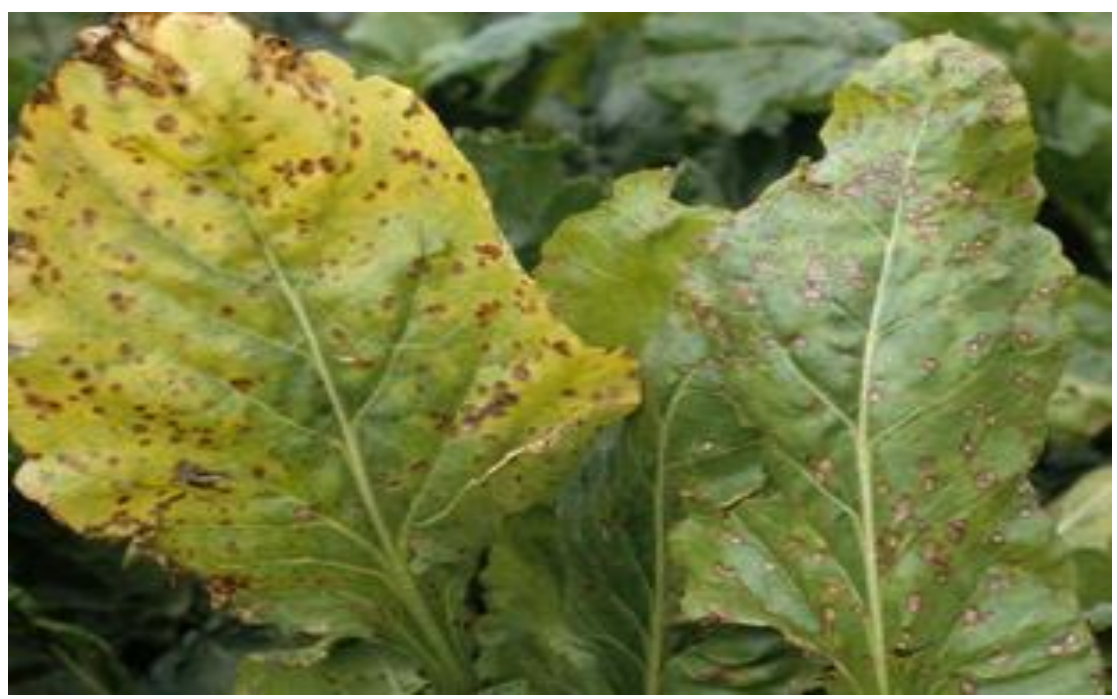

Figure 1. Symptoms of Cercospora Leaf Spot of sugar beet (Harveson et al, 2007).

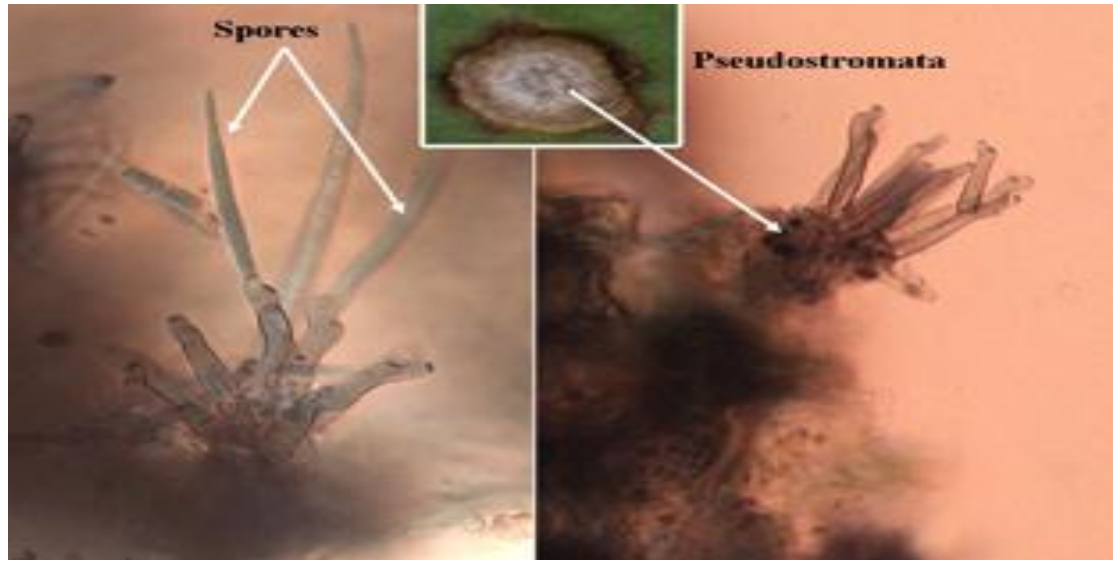

Figure 2. Conidia and pseudostromata of Cercospora beticola (Harveson et al, 2007). 
CLS has a polycyclic disease life cycle where sporulation and dissemination of conidia occurs more than once in the growing season. The pathogen survives in infected sugar beet debris in the field and overwinters as stromata. Conidia of $C$. beticola persist in leaf debris for only 1-4 months but pseudostromata may survive for 1-2 years and serve as sources of primary inoculum. Infection is initiated when conidia land on sugar beet leaf surfaces deposited by wind or water splash. After spore germination, the fungus penetrates stomata to reach the apoplast where effectors released by the invading hyphae facilitate disease establishment by killing the host cells. A higher relative humidity in the stomatal opening compared to lower ambient levels has been correlated with infection through stomates (Daub and Ehrenshaft, 2000;Steinkamp et al, 1979). Conidiophores arise enteroblastically from stromatic cells (Minter et al, 1982) and when conditions are favorable for conidiogenesis; conidia are produced in the resulting necrotic tissue to initiate another disease cycle. Successful infection by $C$. beticola usually requires seven days or more to result in spots on the leaves that are visible to the naked eye. During this time, the fungus is growing from its initial penetration site (stomates on the leaf) to invade and kill cells in the surrounding leaf tissue.

\section{Management of Cercospora Leaf Spot}

Management of CLS requires an integrated approach, which includes early removal of infected debris, crop rotation, resistant varieties, disease scouting and timely application of fungicides (Lamey et al, 1996; Secor et al, 2010). A description of important management strategies is discussed below.

Cultural practices: Since the Cercospora fungus overwinters on infected leaves, cultivation and rotation can reduce levels of overwintering inoculum. At least a three-year 
rotation with crops such as small grains, corn or soybean or dry beans that do not serve as hosts for $C$. beticola is required to reduce carryover of the fungus. It is also suggested that susceptible cultivar should not be planted within 100 yards of the previous year's infected crop (Harveson, 2007). Fall tillage is also one of the effective ways to reduce Cercospora populations but may increase severity of soil erosion during open winter.

Varieties: Varieties of sugar beet differ in their susceptibility towards CLS. The Variety Approval System screens several varieties of sugar beet annually for their reaction to CLS (Jones and Windels, 1991). One of the several screening stations is at Betaseed's Cercospora Screening Nursery in Shakopee, MN, that requires all approved sugar beet varieties to exhibit a 5.2 rating or less on the Klein Wanzlebener Saatzucht scale (KWS Scale). The KWS scale ranges from 0, which means complete resistance, to 9 , which means no resistance. The varieties are rated twice weekly in the field from late July until early September. Screening for the same variety is repeated and the variety is approved based on the average KWS rating for three years (Jones and Windels, 1991). In moderate-resistant cultivars, the disease develops slowly and seldom becomes severe, which can significantly reduce CLS and yield losses. Susceptible cultivars, on the other hand, may have greater yield potential in the absence of leaf spot, but $C$. beticola can easily infect these cultivars and result in severe disease and yield losses (Lamey et al, 1996). Therefore, it is recommended for sugar beet growers to grow only the approved sugar beet varieties with $<5.2$ rating on the KWS scale for CLS resistance.

Chemicals: Sugar beet growers in the early 1900s used inorganic copper to control $C$. beticola on sugar beet (Meriggi et al, 2000). With the advancements in the knowledge of molecular biology and chemistry in the 1950s, scientists developed fungicides, which could 
target important genetic functions and/or enzymes in the fungus and inhibit their growth. Fungicide treatment is the most frequent and efficient means of controlling CLS. Fungicidal sprays are necessary in fields where inoculum has been carried over from previous year, susceptible cultivars are grown, or when the environmental conditions are favorable for disease spread. Disease may begin before the symptoms first appear, hence it is crucial to monitor environmental conditions daily for detecting favorable disease development conditions so as to apply timely fungicide before the infection occurs. Once the symptom appears, fungicide treatment is not as effective (Khan et al, 2007). Several fungicides are registered that differ in their efficacy for controlling CLS (Khan and Smith, 2004). They fall into two categories: protectant and systemic fungicides.

Protectant fungicides act on a leaf surface to kill the germinating spore of the fungi. They offer consistent disease control when applied before the infection has occurred. Because they remain on plant surface, protectant fungicides loose activity after being washed off the plant and must be re-applied to new growth that develops after application. The protectant fungicides include an organo metal, triphenyltin hydroxide (TPTH) (SuperTin ${ }^{\circledR}$, AgriTin $\left.{ }^{\circledR}\right)$, and the ethylene bisdithiocarbamates (Maneb ${ }^{\circledR}$, Mancozeb ${ }^{\circledR}$, Manex ${ }^{\circledR}$ and Penncozeb $\left.{ }^{\circledR}\right)$ (Fishel, 2012).

Both protectant and systemic fungicides are effective in controlling CLS, but systemic fungicides may have the ability to cure the disease even after 24-72 hours of infection. In the US, systemic or translaminar fungicides include benzimidazoles: thiophanate methyl (Topsin-M®, TMethyl $\left.{ }^{\circledR}\right)$; the Demethylation Inhibitors (DMIs): tetraconazole (Domark ${ }^{\circledR}$, Eminent $\left.{ }^{\circledR}\right)$, difenoconazole (Inspire $\left.{ }^{\circledR}\right)$, prothioconazole (Proline $\left.{ }^{\circledR}\right)$; and the strobilurins: pyraclostrobin (Headline $\left.{ }^{\circledR}\right)$ and trifloxystrobin $\left(\right.$ Gem $\left.{ }^{\circledR}\right)$ (Fishel, 2012; Damicone and Smith, 2009; Secor et al, 
2010). Systemic fungicides are absorbed into the plant and move within the plant. These fungicides may move from one surface of the leaf to another or from the spot of application toward the tip of the leaf or plant. These systemic fungicides all have very specific mode of action that frequently allows for the development of resistance.

\section{Fungicide Resistance}

Resistance to fungicides by $C$. beticola has been well documented since early 1970s. (Bugbee, 1995; Georgopoulos and Dovas, 1973; Köller et al, 1988; Ruppel, 1975; Secor et al, 2010). Fungicide resistance can be classified in two categories. Complete insensitivity, also known as qualitative resistance, is usually observed due to a mutation on the target enzyme of fungicides in the fungal pathogen. This results in the complete failure of the fungicide to interact with its target and inhibit fungal growth. Fungicides such as the strobilurins and benzamidazoles are usually observed to show complete resistance because of their single site mode of action. The other type of resistance observed is known as partial insensitivity or quantitative resistance, which is determined by mutations in several genes and results in varying levels of tolerance to a fungicide (Köller et al, 1988). This type of fungicide resistance is observed against those fungicides that have multiple site(s) of action. These include organo metal protectant, triphenyltin hydroxide. However, tetraconazole which belongs to the DMI chemical family has a site specific mode of action is also placed in this category which suggests that apart from target variation, other factors contribute towards fungicide resistance (Karaoglanidis et al, 2002). Some of the most important fungicide groups used to control CLS are: TPTH, Demethylation inhibitor, benzimidazole and Quinone outside inhibitor $\left(\mathrm{Q}_{\mathrm{O}} \mathrm{I}\right)$. 
Triphenyltin hydroxide (TPTH): TPTHs have been an important group of protectant fungicides since 1971 (Campbell et al, 1998). TPTH has multi-site action and kills the fungus by targeting oxidative phosphorylation in fungi. This results in the synthesis of reactive radical oxygen, which disrupts lipid membrane in mitochondria, hence affecting ATP synthase activity and ATP production. This creates energy deficiency due to which the fungus dies. Resistance to TPTH is not normally observed because of their multi-site action, but tolerance to TPTH was previously observed by fungal pathogens including C. beticola (Giannopolitis, 1978; Campbell et al, 1998).

Demethylation inhibitor (DMI) fungicides: DMIs have been an important group of fungicides since their discovery in the 1960s. DMIs are used mostly because of their broadspectrum antifungal activities, protective and curative properties, and low levels of phytotoxicity (Bolton et al, 2012). They have the ability to mix with other fungicides which helps in delaying resistance by fungal pathogens. DMIs act by inhibiting the cytochrome P450-dependent sterol $14 \alpha$-demethylase enzyme (CYP51), which is required for biosynthesis of the cell membrane component ergosterol in fungi (Karaoglanidis, 2010). They act on hyphal growth, but do not inhibit spore germination. DMIs have an excellent translaminar movement which helps the fungicide to move from tissue to tissue and leaf to leaf (Ma, 2006). Resistance to DMIs has been reported in many fungal pathogens (Liu, 2011; Ma, 2006), including C. beticola (Bolton et al, 2012; Karaoglanidis, 2000; Secor et al, 2010). Resistance mechanisms to DMI fungicides include (i) mutations in the Cyp51 gene that maintain appropriate protein function while avoiding inhibition by the DMI fungicide (Deleye et al, 1997), (ii) overexpression of the Cyp51 gene leading to an excess of the CYP51 DMI target, and (iii) reduction of the intracellular fungicide concentration by means of increased ATP-binding cassette (ABC) or major facilitator 
superfamily (MSF) transporter efflux activity (Del Sorbo, 2000). Bolton et al, (2012) in their study on DMI-resistance found that overexpression of Cyp51 gene in DMI-resistant isolates as compared to DMI-sensitive isolates contributed to DMI-resistance in C. beticola.

Benzimidazole: The widespread use of the benzimidazole class of fungicides began during the late 1960s, and the first report of fungicide resistance in C. beticola was reported in the early 1970s (Ruppel and Scott, 1975). Resistance to benzimidazoles is qualitative, which means that they have a single site of action, and hence, suffer higher risk of resistance by the fungal pathogens. Benzimidazole interferes with the binding of $\beta$-tubulin proteins as they form microtubules in fungi. Resistance to benzimidazole is due to single mutation observed in the gene coding for cytoplasmic protein $\beta$-tubulin in the fungal pathogen, conferring complete resistance (Upchurch et al, 1991). Glutamic acid is seen to be substituted by alanine, glycine, lysine, or glutamine at the $198^{\text {th }}$ codon (Albertini et al, 1999; Cunha and Rizzo, 2003). Benzimidazole resistant $C$. beticola isolates have been characterized with glutamic acid to alanine substitution (Davidson et al, 2005).

Strobilurins: Quinione-outside inhibitors (QOIs) belongs to a group of fungicides named strobilurins. The first fungicides from this family were isolated from wood-rotting mushroom fungi, Strobilurus tenacellus, and the name strobilurin was coined in recognition of the genus it was prepared from. QoIs control a very wide array of fungal diseases, including diseases caused by water molds, downy mildews, powdery mildews, fruit rotters, and rusts. They are also used on several crops, including cereals, field crops, fruits, tree nuts, vegetables, trufgrasses, and ornamentals (Vincelli, 2002). These fungicides act by binding the quinol oxidation site of the cytochrome $\mathrm{bc}_{1}$ enzyme complex $\left(\mathrm{Q}_{\mathrm{O}} \mathrm{I}\right)$. This inhibition blocks the electron transfer between 
cytochrome $\mathrm{b}$ and cytochrome $\mathrm{c}_{1}$ complexes, thereby inhibiting ATP production. Eventually, the fungus dies due to energy deficiency. Cytochrome $b$ is a membrane protein forming the core of the mitochondrial $b_{1}$ complex and is encoded by the cytochrome $b(c y t b)$ gene.

Because $\mathrm{Q}_{\mathrm{O}} \mathrm{Is}$ have a single site target to control the disease, hence the pathogen may show qualitative resistance. Resistance observed by several plant pathogens towards $\mathrm{Q}_{\mathrm{O}} \mathrm{I}$ is due to point mutation associated in the $c y t b$ gene. The target site mutations F129L, G137R, and G143A appear to play a central role in $\mathrm{Q}_{\mathrm{O}} \mathrm{I}$ resistance by plant pathogenic fungi (Fisher and Meunier, 2008). G143A has been reported by several QoI resistant pathogens (Fisher and Meunier, 2008; FRAC 2011; Gisi et al, 2008). G143A mutation is observed to be a reason for complete resistance in plant pathogens while F129L and G137R mutations are associated with moderate levels of resistance and the pathogens can be controlled with timely application of $\mathrm{Q}_{\mathrm{O}} \mathrm{I}$ fungicides (Bartlett et al, 2002; Sierotzki et al, 2007).

QOIs have been used all over the world including Europe to control CLS. Azoxystrobin was first registered in 2009 in France, which was followed by trifloxystrobin and pyraclostrobin in 2010 (Marc Richard-Molard, personal communication). In Italy, azoxystrobin, trifloxystrobin, and pyraclostrobin were first used to control CLS in 2001, 2002, and 2009, respectively (F. Cioni, personal communication). In the US, trifloxystrobin was registered for CLS in 2003 and pyraclostrobin in 2004. Since the time these fungicides were registered in Europe until this study, there was no report of reduced sensitivity or development of resistance in naturally occurring field isolates of $C$. beticola to $\mathrm{Q}_{\mathrm{O}} \mathrm{I}$ fungicides in any of the European countries. However, some level of insensitivity by the US strains of Cercospora beticola to azoxystrobin were detected (Larson, 2004) and in a recent study, mutants of $C$. beticola with high, moderate and low levels 
of insensitivity to QoIs were isolated from a wild-type strain after ultraviolet mutagenesis and were observed to show a substitution from glycine to serine at $143^{\text {rd }}$ codon position in the $c y t b$ gene (Malandrakis et al, 2006).

The primary purpose of this study, therefore, was to screen naturally occurring $C$.

beticola isolates collected in the sugar beet growing regions of France and Italy for resistance to Q $\mathrm{O}$ Is, which has not been previously done, and to assess for the reason of $\mathrm{Q}_{\mathrm{O}} \mathrm{I}$ resistance if detected. The results of this study could demonstrate the importance of monitoring $\mathrm{Q}_{\mathrm{O}} \mathrm{I}$ sensitivity in $C$. beticola as an important fungicide resistance management strategy.

\section{References}

Albertini, C.,Gredt, M., andLeroux, P. 1999. Mutations of the $\beta$-tubulin gene associated with different phenotypes of benzimidazole resistance in the cereal eyespot fungi Tapesiayallundaeand Tapesiaacuformis. Pesticide Biochemistry and Physiology 64:1731.

Atiyeh, H., and Duvnjak Z. 2002.Production of fructose and ethanol from sugar beet molasses using Saccharomyces cerevisiaeATCC 36858.Biotechnology Press. 18:234-239.

Bartlett, D. W., Clough, J. M., Godwin, J. R., Hall, A. A., Hamer, M., and Parr-Dobrzanski, B. 2002. The strobilurin fungicides. Pest Management Science 58:649-662.

Bent, K. J., Cole, A. M., Turner, J. A. W., andWoolner, M. 1971. Resistance of cucumber powdery mildew to dimethirimol.Proc. 6 Brit. Insectic.Fungic. Conf.274-282. 
Bolton, M. D., Birla, K., Rivera-Varas, V., Rudolph, K., and Secor, G. A. 2012. Characterization of CbCyp51 from field isolates of Cercosporabeticola. Phytopathology 102:298-305.

Bugbee, W. M. 1995. Cercospora beticola tolerant to triphenyltin hydroxide. J. Sugar Beet Res. 32:167-174.

Campbell, L .G., Smith, G. A., Lamey, H. A., and Cattanach, A. W. 1998. Cercospora beticola tolerant to triphenyltin hydroxide and resistant to thiophanate methyl in North Dakota and Minnesota.Journal of Sugar Beet Research 35:29-41.

Cattanach, A. W., Dexter, A. G., and Oplinger, E. S. 1991.Sugarbeets. In: Alternative Field Crops Manual. Madison: University of Wisconsin Extension.

Cooke, D. A., and Scott, R. K. 1993.The sugar beet crop: science into practice. Chapman and Hall, London, 14-19.

Coons, G. H. 1949. The sugar beet: Product of science. Sci. Mon. 68:149-164.

Cunha, M. G., and Rizzo, D. M. 2003. Development of fungicide cross resistance in Helminthosporiumsolanipopulations from California. Plant Disease 87:798-803.

Damicone. J., and Smith, D. 2009.Fungicide resistance management. Oklahoma Cooperative Extension Service, EPP-7663:1-8

Daub, M. E., and Chung, K. R. 2007.Cercosporin: A photoactivated toxin in plant disease. Annual Reviews in Phytopathology DOI:10.1094/APSnetFeature/2001-0207. 
Daub, M. E., and Ehrenshaft, M. 2000. The photoactivatedCercospora toxin cercosporin: contributions to plant disease and fundamental biology. Annual Reviews in Phytopathology 38:461-490.

Daub, M. E., Herrero, D., and Chung, K. R. 2005.Photoactivatedperylenequinone toxins in fungal pathogenesis of plants.FEMS Microbiol.Lett. 252:197-206.

Davidson, R. M., Hanson, L. E., Franc, G. D., and Panella, L. 2005. Analysis of $\beta$-tubulin gene fragments from benzimidazole-sensitive and-tolerant Cercospora beticola. J. Phytopathology 154:321-328.

De-Rougemont, G. M. 1989.Crops of Britain and Europe.Collins, London: 241-243.

Del Sorbo, G., Andrade, A. C., Van Nistelrooy, J. G. M., Van Kan J. A. L., Balzi, E, and de Waard, M. A. 1997. Multidrug resistance in Aspergillusnidulans involves novel ATPbinding cassette transporters. Mol. Gen. Genet. 254:417-426.

Del Sorbo, G., Schoonbeek, H. J., and De Waard, M. A. 2000. Fungal transporters involved in efflux of natural toxic compounds and fungicides. Fungal Genet. Biol. 30:1-15.

Deleye, C., Laigret, F., andCorioCostet, M. F. 1997. A mutation in the 14 $\alpha$-demethylase gene of Uncinulanecatorthat correlates with resistance to a sterol biosynthesis inhibitor.Applied Environmental Microbiology 63:2966-2970.

Elliot, M. C and Weston, G. D. 1993.Biology and physiology of the sugar-beet plant. In:The sugar beet crop: science into practice. Eds. DA Cooke and RK Scott. Chapman and Hall, London: 37-66. 
FRAC. (2011). FRAC list of plant pathogenic organisms resistant to disease control agents.

Fishel, F. M. 2012. Fungicide resistance action committee's (FRAC) classification scheme of fungicides according to mode of action. Florida Cooperative Extension Service, Institute of Food and Agricultural Sciences, University of Florida: PI-94.

Fisher, N., and Meunier, B. 2008. Molecular basis of resistance to cytochrome $b c 1$ inhibitors. FEMS Yeast Research 8:183-192.

Georgopoulos, S. G., andDovas, C. 1973.A serious outbreak of strains of Cercospora beticola resistant to benzimidazole fungicides in northern Greece. Plant Disease Reporter 57:321324.

Gill, N. T., andVear, K. C. 1980. Agricultural botany. 1. dicotyledonous crops. (3 ${ }^{\text {rd }}$ ed.). Duckworth, London: Gerald Duckworth \& co ltd.

Giannopolitis, C. N. 1978. Occurrence of strains of Cercospora beticola resistant to triphenyltin fungicides in Greece. Plant Dis. Rep. 62:205-208.

Gisi, U., Sierotzki, H., Cook, A., and McCaffery, A. 2002. Mechanisms influencing the evolution of resistance to Qo inhibitor fungicides. Pest Management Science 58:859-867.

Harveson, R., Panella, L.W., and Lewellen, R.T. 2009.Introduction - History of Sugar Beet Production and Usage. Pages 1-2 In: Compendium of Beet Diseases and Insects, edited by R.M Harveson, L.E. Hanson, and G. L. Hein, etd. APS Press, St. Paul. MN. Page: 140.

Harveson. R. M. 2007, Cercospora leaf spot of sugar beet. University of Nebraska-Lincoln Extension. G1753. 
Jacobsen, B. J., and Franc, G. D. 2009, Cercospora leaf spot. Pages 7-10, In: Compendium of Beet Diseases and Insects, $2^{\text {nd }}$ ed. R. M. Harveson, L. E. Hanson, and G.L. Hein, eds. American Phytopathological Society, St. Paul, MN.

Jones, R. K., and Windels, C. E. 1991. A management model for Cercospora Leaf Spot of sugar beets. Minnesota Extension Service, University of Minnesota.AG-FO-5643-E.

Karaoglanidis, G. S., Ioannidis, P. M., andThanassoulopoulos C. C. 2002.Changes in sensitivity of Cercospora beticola populations to sterol demethylation inhibiting fungicides during a 4-year period in northern Greece. Plant Pathology 51:55-62.

Karaoglanidis, G. S., and Ioannidis, P. M. 2010.Fungicide resistance of Cercospora beticola in Europe.In: Cercospora Leaf Spot of Sugar Beet and Related Species. Pages: 189-211.

Karaoglanidis, G. S., Ioannidis, P. M., and Thanassoulopoulos, C. C. 2000. Reduced sensitivity of Cercospora beticola isolates to steroldemethylation-inhibiting fungicides. Plant Pathol. 49:567-572.

Khan, J., del Rio, L. E., Nelson, R., Rivera-Varas, V., Secor, G. A., and Khan, M. F. R. 2008. Survival, dispersal, and primary infection site for Cercospora beticola in sugar beet. Plant Dis. 92:741-745.

Khan, J., del Rio, L. E., Nelson, R., and Khan, M .F. R. 2007. Improving the Cercospora leaf spot management model for sugar beet in Minnesota and North Dakota. Plant Dis. 91:1105-1108.

Khan, M. F. R. and Smith, L. J. 2004.Evaluating fungicides for controlling Cercospora leaf spot on sugar beet. Crop Protection 24(1):79-86. 
Köller W. 1988. Sterol demethylation inhibitors: mechanisms of action and resistance. In: Delp CJ, ed. Fungicide Resistance in North America. St Paul, MN, USA: APS Press. Pages: $79-88$.

Lamey. H. A., Cattanach. A. W., Bugbee. W. M.,and Windels. C. E. 1996, Cercospora leafspot of sugarbeet. NDSU Extension Service, Page-764.

Larson, B. J. 2004. Integrated management of Cercospora leaf-spot of sugar beet.M.Sc. thesis, Montana State University, Bozeman.

Liu, X., Yu, F., Schnabel, G., Wu, J., Wang, Z., and Ma, Z. 2011.ParalogousCyp51 Genes in Fusariumgraminearummediate differential sensitivity to sterol demethylation inhibitors. Fungal Genet. Biol. 48:113-123.

Loannidids, P.M. and Karaoglanidis, G.S. 2000.Resistance of Cercospora beticolaSacc.To fungicides. Adv. Sugar Beet Res. IIRB, 2, 123-147.

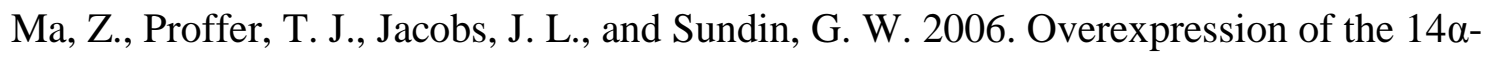
demethylase target gene (CYP51) mediates fungicide resistance in Blumeriellajaapii. Appl. Environ. Microbiol. 72:2581-2585.

Malandrakis, A. A., Markoglou, A. N., Nikou, D. C., Vontas, J. G., and Ziogas, B. N. 2006 Phytopathological and molecular characterization of strobilurin resistance in Cercospora beticola. Eur. J. Plant Pathol. 116:115-166.

Malandrakis, A. A., Markoglou, A. N., Nikou, D. C., Vontas, J. G., and Ziogas, B. N. 2011. Molecular diagnostics for detecting the cytochrome b G143S - $\mathrm{Q}_{\mathrm{O}} \mathrm{I}$ resistance mutation in Cercospora beticola.Pesitcide Biochemistry and Physiology 100:87-92. 
Meriggi, P., Rosso, F., loannides, P.M. and Ayala Garcia, J. 2000. Fungicide treatments against Cercospora leaf spot in sugar beet (Beta vulgaris L.). Adv. Sugar Beet Res. IIRB 2:77102.

Minter, D. W., Kirk, P. M., and Sutton, B. C. 1982.Holoblasticphialides. Transactions of the British Mycological Society 79:75-79.

Ruppel, E. G., and Scott, P. R. 1975. Strains of Cercospora beticola resistant to benomyl in the U.S.A. Plant Disease Reporter 58:434-436.

Schnieder, K., Schafer-Pregl, R., Borchardt, C., andSalamini, F. 2002. Mapping QTLs for sucrose content, yield and quality in a sugar beet population fingerprinted by EST-related markers. Theoretical and Applied Genetics 104:1107-1113.

Secor, G. A., Rivera, V. V., Khan, M. F. R., and Gudmestad, N. C. (2010).Monitoring fungicide sensitivity of Cercospora beticola of sugar beet for disease management decisions. Plant Diseases 94:1272-1282.

Shane, W. W., and Teng, P. S. 1992.Impact of Cercospora leaf spot on root weight, sugar yield, and purity of Beta vulgaris. Plant Dis. 76:812-820.

Steinkamp, M. P., Martin, S. S., Hoefert, L. L., and Ruppel, E. G. 1979.Ultrastructure of lesions produced by Cercospora beticola in leaves of Beta vulgaris. Physiol. Plant Pathol. $15: 13-26$.

Sierotzki, H., Frey, R., Wullschleger, J., Palermo, S., Karlin, S., Godwin, J., and Gisi, U. 2007.Cytochrome $b$ gene sequence and structure of Pyrenophora teres and P. triticirepentis and implications for $\mathrm{Q}_{\mathrm{O}} \mathrm{I}$ resistance.Pest Management Science 63:225-233. 
Ulber, R., Faurie, R., Sosnilza, P., Fischer, L., Stark, E., Harbeck, C., andScheper, T. 2000. Monitoring and control of industrial downstream processing of sugar beet molasses.Journal of Chromatography 882:329-334.

Upchurch, R. G., Ehrenshaft, M., Walker, D. C., Sanders, L. A. 1991.Genetic transformation system for the fungal soybean pathogen Cercospora kikuchii.Applied Environmental Microbiology 57:2935-2939.

Vereijssen, J., Schneider, J. H. M., Termorshuizen, A. J., Jeger, M. J. 2003. Comparison of two disease assessment methods for assessing Cercospora leaf spot in sugar beet. Crop Protection 22:201-209.

Vincelli, P. 2002. QoI (Strobilurin) Fungicides: Benefits and Risks. The Plant Health Instructor DOI: 10.1094/PHI-I-2002-0809-02

Weiland, J. and Koch, G. 2004, Sugarbeet leaf spot disease (Cercospora beticola Sacc.). Molecular Plant Pathology 5: 157-166. DOI: 10.1111/j.1364-3703.2004.00218.x.

Winner, C. 1993, History of the crop. In: The sugar beet crop: science into practice. Eds. DA Cooke and RK Scott. Chapman and Hall, London. Pages 1-35. 


\title{
PAPER: CHARACTERIZATION OF CYTOCHROME BFROM EUROPEAN FIELD ISOLATES OF CERCOSPORA BETICOLA WITH QUINONE OUTSIDE INHIBITOR RESISTANCE ${ }^{1}$
}

Reproduced from: Birla, K., Rivera, V. V., Secor, G. A., Khan, M .F. R., and Bolton, M. D. 2012. Characterization of cytochrome $b$ from European field isolates of Cercospora beticola with quinone outside inhibitor resistance. Eur. J. Plant Pathol. 134:475-488.

\begin{abstract}
Cercospora leaf spot (CLS), caused by the fungal pathogen Cercospora beticola, is the most important foliar disease of sugar beet worldwide. Control strategies for CLS rely heavily on quinone outside inhibitor ( $\left.\mathrm{Q}_{\mathrm{O}} \mathrm{I}\right)$ fungicides. Despite the dependence on $\mathrm{Q}_{\mathrm{O}} \mathrm{Is}$ for disease control for more than a decade, a comprehensive survey of $\mathrm{Q}_{\mathrm{O}} \mathrm{I}$ sensitivity has not occurred in the sugar beet growing regions of France or Italy. In 2010, we collected 866 C. beticola isolates from sugar beet growing regions in France and Italy and assessed their sensitivity to the $\mathrm{Q}_{\mathrm{O}} \mathrm{I}$ fungicide pyraclostrobin using a spore germination assay. In total, 213 isolates were identified with $\mathrm{EC}_{50}$ values greater than $1.0 \mu \mathrm{g} \mathrm{ml}^{-1}$ to pyraclostrobin, all of which originated from Italy. To gain and understanding of the molecular basis of QoI resistance, we cloned the full-length coding region of Cbcytb, which encodes the mitochondrial QoI-target enzyme cytochrome b in C. beticola. $C b c y t b$ is a 1,162-bp intron-free gene with obvious homology to other fungal cytb genes.

${ }^{1}$ The material in this chapter was co-authored by Keshav Birla, Viviana Rivera-Varas, Gary A. Secor, Mohamed F. R. Khan and Melvin D. Bolton. K. Birla had the primary responsibility of characterizing $\mathrm{Q}_{\mathrm{O}} \mathrm{I}$ resistance at molecular level, V. V. Rivera equally contributed to this paper and had the primary responsibility for isolate collection and sensitivity experiments. G. A. Secor, M. F. R. Khan and M. D. Bolton guided the whole study and were the proofreaders and provided comments on the content.
\end{abstract}


Sequence analysis of $C b c y t b$ was carried out in $32 \mathrm{Q}_{\mathrm{O}} \mathrm{I}-$ sensitive $\left(<0.080 \mu \mathrm{g} \mathrm{ml}^{-1}\right)$ and $27 \mathrm{Q}_{\mathrm{O}} \mathrm{I}-$ resistant $\left(>1.0 \mu \mathrm{g} \mathrm{ml}^{-1}\right)$ isolates. All tested $\mathrm{Q}_{\mathrm{O}} \mathrm{I}$-resistant isolates harbored a point mutation in Cbcytb at nucleotide position 428 that conferred an exchange from glycine to alanine at amino acid position 143 (G143A). A PCR assay developed to discriminate $\mathrm{Q}_{\mathrm{O}} \mathrm{I}-$ sensitive and $\mathrm{Q}_{\mathrm{O}} \mathrm{I}-$ resistant isolates based on the G143A mutation could detect and differentiate isolates down to approximately $25 \mathrm{pg}$ of template DNA. Microsatellite analyses suggested that $\mathrm{Q}_{\mathrm{O}} \mathrm{I}$ resistance emerged independently in multiple genotypic backgrounds at multiple locations. Our results indicate that $\mathrm{Q}_{\mathrm{O}} \mathrm{I}$ resistance has developed in some $C$. beticola populations in Italy and monitoring the G143A mutation is essential for fungicide resistance management in this pathosystem.

\section{Introduction}

Cercospora leaf spot (CLS), caused by the fungus Cercospora beticola (Sacc.), is one of the most serious diseases of sugar beet (Beta vulgaris L.) worldwide. The fungus is most damaging in regions with warm, humid summers, particularly after crop canopies close (Khan et al, 2009). Infection is initiated when spores land on sugar beet leaf surfaces by wind or water splash. After spore germination, the fungus penetrates stomata to reach the apoplast where effectors released by the invading hyphae facilitate disease establishment (Daub and Ehrenshaft, 2000; Steinkamp et al, 1979). Conidia produced in the resulting necrotic tissue can initiate another disease cycle provided environmental conditions are favorable. The disease causes a reduction in root harvest weight and extractable sucrose. CLS control measures include the planting of tolerant varieties and crop rotation, but the disease is managed most effectively when 
combined with timely fungicide applications (Bolton et al, 2012a; Kaiser et al, 2010;

Karaoglanidis and Ioannidis, 2010; Secor et al, 2010).

An important group of fungicides used to manage leaf spot is the strobilurins or quinone outside inhibitors ( $\left.\mathrm{Q}_{\mathrm{O}} \mathrm{Is}\right)$. These fungicides act by binding the quinol oxidation site of the cytochrome $\mathrm{bc}_{1}$ enzyme complex. This inhibition blocks the electron transfer between cytochrome $\mathrm{b}$ and cytochrome $\mathrm{c}_{1}$ complexes, which disrupts ATP production and consequently leads to an energy deficit in sensitive fungi (Bartlett et al, 2002; Fisher and Meunier, 2008). Cytochrome $\mathrm{b}$ is a membrane protein forming the core of the mitochondrial $b_{1}$ complex and is encoded by the cytochromeb (cytb) gene. Point mutations in $c y t b$ that encode single amino acid substitutions have been associated with resistance to $\mathrm{Q}_{\mathrm{O}} \mathrm{I}$ fungicides. The target site mutations F129L, G137R, and G143A appear to play a central role in the mechanism of QoI resistance in plant pathogenic fungi (Fisher and Meunier, 2008). G143A has been reported in most QoIresistant pathogens (Fisher and Meunier, 2008; FRAC, 2011; Gisi et al, 2002). When the G143A mutation dominates in a pathogen population, there is a consistent association with a loss of disease control (Gisi et al, 2002). Moreover, isolates with the G143A mutation may not suffer from a significant fitness penalty (Banno et al, 2009; Chin et al, 2001; Sierotzki et al, 2000). The F129L and G137R mutations are associated with moderate levels of resistance and populations of these fungi are still controlled with $\mathrm{Q}_{\mathrm{O}} \mathrm{I}$ fungicides when applied at recommended rates (Bartlett et al, 2002; Sierotzki et al, 2007). Laboratory mutants of C. beticola encoding a G143S mutation have been shown to have reduced sensitivity to $\mathrm{Q}_{\mathrm{O}} \mathrm{I}$ fungicides (Malandrakis et al, 2006), but this mutation has not been found in nature (Malandrakis et al, 2011). Molecular techniques exploiting point mutations associated with fungicide-resistance that discriminate resistant isolates have been developed for a number of pathosystems (Fontaine et al, 2009; 
Pasche et al, 2005; Sierotzki et al, 2007). Such assays provide a means for rapid, accurate, and reliable detection of fungicide resistance and are an important tool for fungicide resistance management.

Qo Is such as pyraclostrobin have become a critical component of CLS management because of their broad-spectrum antifungal activities and low level of phytotoxicity (Secor et al, 2010). Moreover, $Q_{0} I s$ have both preventative and curative properties (Bartlett et al, 2002). However, the Fungicide Resistance Action Committee (FRAC) considers $Q_{\mathrm{O}}$ Is a high-risk for resistance development due to their single-site mode of action (2011). Moreover, C. beticola represents a classic 'high-risk' pathogen in terms of resistance development due to its high genetic variability, abundant sporulation, polycyclic nature, and the high number of sprays required to control the disease (Bolton et al, 2012b; Secor et al, 2010). Despite these risks, there have been no reports of European $C$. beticola field isolates with resistance to QoIs to date (Karaoglanidis and Ioannidis, 2010; Malandrakis et al, 2011). Nonetheless, monitoring QoI sensitivity in C. beticola field isolates is important for fungicide resistance management programs. Although sugar beet growers have depended on $\mathrm{Q}_{0} \mathrm{Is}$ for disease control for more than a decade, a comprehensive survey of $\mathrm{Q}_{\mathrm{O}} \mathrm{I}$ sensitivity has not occurred in European sugar beet growing regions. Therefore, the objectives of this study were to (i) determine pyraclostrobin $\mathrm{EC}_{50}$ values of $C$. beticola isolates collected from sugar beet growing regions of France and Italy, (ii) clone the full-length $C$. beticola cytb (Cbcytb) coding sequence, (iii) sequence $C b c y t b$ from $\mathrm{Q}_{\mathrm{O}} \mathrm{I}-$ resistant and $\mathrm{Q}_{\mathrm{O}} \mathrm{I}-$-sensitive isolates to assess whether any mutations correlate with $\mathrm{Q}_{\mathrm{O}} \mathrm{I}$ resistance, and if a novel mutation in Cbcytb correlates with QoI-resistance, (iv) develop allelespecific primers that can be used for the detection of $\mathrm{Q}_{\mathrm{o}} \mathrm{I}-$-resistant isolates. 


\section{Material and Methods}

Sample collection and fungal isolation: Sugar beet leaves with CLS were collected from commercial fields within the French departments of Aisne, Aube, Nord (near Ochies or Templeuve), Somme, and the French region of Champagne in September 2010. Samples were also collected from commercial fields and research plots within the Italian provinces of Bologna, Ferrara, Rovigo, and Venezia in September 2010. Isolates taken from research plots were natural infestations. Individual leaf spots were excised, placed in individual wells of 96-well PCR plates (USA Scientific, Ocala, FL), and hand-carried to our laboratory for immediate processing. Conidia were harvested by adding $50 \mu 1$ of T-water $(0.06 \%$ (v/v) Tween 20 (Sigma-Aldrich, St. Louis, MO), $0.02 \%$ (w/v) filter-sterilized ampicillin added after the solution had been autoclaved) to each PCR plate well. The lesion was gently scraped with a pipette tip to liberate conidia into the T-water. The conidia-laden T-water was collected and transferred to water agar plates $(1.5 \%$ (w/v) Difco agar (BD, Franklin Lakes, NJ), 0.02\% (w/v) filter-sterilized ampicillin added after the solution had been autoclaved) for $24 \mathrm{~h}$ at $22^{\circ} \mathrm{C}\left( \pm 1^{\circ} \mathrm{C}\right)$ to initiate conidia germination. One germinated conidium was transferred to a clarified V8-medium plate (10\% (v/v) clarified V8 juice (Campbell's Soup Co., Camden, NJ), 0.5\% (w/v) $\mathrm{CaCO}_{3}$, and 1.5\% (w/v) agar (BD)) and was incubated at $25^{\circ} \mathrm{C}$ for two weeks. This single spore-derived colony was the source inoculum plate for subsequent fungicide sensitivity assays and Cbcytb characterization experiments.

Fungicide sensitivity assays and statistical analysis: $\mathrm{EC}_{50}$ values were calculated using technical grade pyraclostrobin (BASF, Triangle Park, NC) using previously published procedures (Secor and Rivera, 2012). Briefly, agar plugs (5 mm each) were taken from the 
leading edge of colony growth of the original non-amended V8-agar plates described above and placed on V8-agar plates. Spores were harvested from 15-day-old culture plates and transferred to non-amended water agar medium (1.5\% (w/v) Difco agar (BD)) and water agar plates amended with serial ten-fold dilutions of active ingredient from 0.001 to $1.0 \mu \mathrm{g} \mathrm{ml}^{-1}$. In addition, 21 isolates shown to have $\mathrm{EC}_{50}$ values $>1.0 \mu \mathrm{g} \mathrm{ml}^{-1}$ (See Results) were re-analyzed using serial ten-fold dilutions of pyraclostrobin from 0.01 to $100 \mu \mathrm{g} \mathrm{ml}^{-1}$ to calculate their $\mathrm{EC}_{50}$ value in this range. All fungicide-amended plates contained salicylhydroxamic acid (SHAM; Sigma-Aldrich) at $100 \mu \mathrm{g} \mathrm{ml}^{-1}$ to prevent alternative respiration. After a 16 hour incubation, the percentage of germinated spores was used to calculate the $\mathrm{EC}_{50}$ value for pyraclostrobin as described by Secor and Rivera (2012). Median and mean $\mathrm{EC}_{50}$ values were calculated for each location using Microsoft Excel 2010. A value of $1.0 \mu \mathrm{g} \mathrm{ml}^{-1}$ was used for all isolates with $\mathrm{EC}_{50}$ values $>1.0 \mu \mathrm{g}$ $\mathrm{ml}^{-1}$ for median and mean calculations.

Cbcytb cloning and sequence analysis: Primers 503 and 504 (Table 1) designed on GenBank Accession \# EF176921 (Malandrakis et al, 2006) were used to amplify a fragment of Cbcytb using C. beticola isolate 1-18 as template. PCR was conducted using GoTaq Flexi DNA Polymerase kit (Promega, Madison, WI) following the manufacturer's instructions with a final $\mathrm{MgCl}_{2}$ concentration of $3.5 \mathrm{mM}$. PCR conditions were as follows: an initial $95^{\circ} \mathrm{C}$ denaturation step for $5 \mathrm{~min}$ followed by denaturation for $15 \mathrm{~s}$ at $95^{\circ} \mathrm{C}$, annealing for $30 \mathrm{~s}$ at $50^{\circ} \mathrm{C}$ and extension for $60 \mathrm{~s}$ at $72^{\circ} \mathrm{C}$ for 30 cycles. PCR amplicons were sequenced directly (McLab, South San Francisco, CA). Consensus sequences were assembled using Vector NTI (Invitrogen, Carlsbad, CA) software. The DNA Walking SpeedUp Kit II (Seegene, Rockville, MD) and primers (Table 1) designed on the derived Cbcytb sequence were used for one round of DNA walking to identify upstream sequence following the manufacturer's instructions. Subsequently, 
an additional round of DNA walking was used to identify sequence further upstream and one round of DNA walking was used to identify downstream sequence with primers (Table 1) designed on the derived $C b c y t b$ sequence using the Genome Walker Universal kit (Clontech Laboratories, Inc., Mountain View, CA) following the manufacturer's instructions.

Sixty-eight isolates that exhibited a wide-range of $\mathrm{EC}_{50}$ values to pyraclostrobin were used to assess $C b c y t b$ sequence variation. Liquid cultures were initiated by placing an agar plug taken from the leading edge of the clarified V8-medium plates (described above) into a $250 \mathrm{ml}$ flask containing $50 \mathrm{ml}$ potato dextrose broth (BD). Isolates were allowed to grow for approximately 4 days after which mycelia were harvested using a Büchner funnel. DNA was isolated using the CTAB method (Stewart and Via, 1993). For each isolate, Cbcytb gene and flanking sequences were generated with three PCR reactions using primer combinations 660/661, 714/715, and 658/659 (Table 1) that produced overlapping sequence fragments. PCR was conducted using the GoTaq Flexi DNA Polymerase kit (Promega) following the manufacturer's instructions with a final $\mathrm{MgCl}_{2}$ concentration of $3.5 \mathrm{mM}$. PCR conditions were as follows: an initial $94^{\circ} \mathrm{C}$ denaturation step for $3 \mathrm{~min}$ followed by denaturation for $30 \mathrm{~s}$ at $94^{\circ} \mathrm{C}$, annealing for $30 \mathrm{~s}$ at $58^{\circ} \mathrm{C}$ and extension for $60 \mathrm{~s}$ at $72^{\circ} \mathrm{C}$ for 36 cycles, followed by a final extension at $72^{\circ} \mathrm{C}$ for 5 min. PCR amplicons were sequenced directly (McLab). Consensus sequences were generated and analyzed for polymorphisms using Vector NTI (Invitrogen) software. Consensus sequences were compared with previously reported sequences using BLAST (Altschul et al, 1990). Open reading frames were predicted using genetic code 4 in the ORF Finder tool (http://www.ncbi.nlm.nih.gov/projects/gorf/). 
Table 1. Primers used in this study

\begin{tabular}{|c|c|c|c|}
\hline Primer & Specificity/role & Sequence $\left(5^{\prime}\right.$ to $\left.3^{\prime}\right)$ & $\begin{array}{c}\text { Amplicon } \\
\text { size (bp) }\end{array}$ \\
\hline 503 & Cbcytb For & AGAGCATATGATGAGAGAC & \multirow{2}{*}{734} \\
\hline 504 & Cbcytb Rev & CTGTGAAAGGCATAGTTAGT & \\
\hline 572 & Cbcytb/5' walk round I (TSP1) & CTCAACTATGTCTTGTCC & NA \\
\hline 573 & Cbcytb/5' walk round I (TSP2) & CTTGTCCTACTCATGGTATTGC & NA \\
\hline 574 & Cbcytb/5' walk round I (TSP3) & GCACCTCATAAAGACATTTGTC & NA \\
\hline 633 & Cbcytb/5' walk round II (GSP1) & CTTCAAGTACGCTAGGATTGTAGTG & NA \\
\hline 634 & Cbcytb/5' walk round II (GSP2) & CACAGGTAACTAATATTTGAAGGCTG & NA \\
\hline 635 & Cbcytb/3' walk (GSP1) & GAGGATTACAGTTCAGACCTTTAAG & NA \\
\hline 636 & Cbcytb/3' walk (GSP2) & GATGCAATTGGGTGCTAAACACG & NA \\
\hline 660 & Cbcytb/beginning fragment For & GACACAGGGGTTATCACATCA & \multirow{2}{*}{668} \\
\hline 661 & Cbcytb/beginning fragment Rev & AAGAAGAAAAATGCTGAAGCTG & \\
\hline 714 & Cbcytb/middle fragment For & AGAACATATTATGAGAGAC & \multirow{2}{*}{734} \\
\hline 715 & Cbcytb/middle fragment Rev & CTGTGAAAGGCATAGTTAGT & \\
\hline 658 & Cbcytb/end fragment For & AATTACGTTGTGGCCAATCC & \multirow{2}{*}{$518-519$} \\
\hline 659 & Cbcytb/end fragment Rev & CAACCGGTATTATTTGAGGATTT & \\
\hline 692 & MAMA-sensitive For & CTTACGGACAAATGTCTTTATGATG & \multirow{2}{*}{613} \\
\hline 694 & MAMA-sensitive Rev & TGCATCAATAATAAGAAATTTGCTACA & \\
\hline 695 & MAMA-resistant For & CTTACGGACAAATGTCTTTATGATC & \multirow{2}{*}{381} \\
\hline 696 & MAMA-resistant Rev & TGGCCACAACGTAATTCTCA & \\
\hline 718 & Cbcytb CDS For & ATGAGAATATTTAAAAGTCACCCTTT & \multirow{2}{*}{$1286-1287$} \\
\hline 719 & Cbcytb CDS Rev & CAACCGGTATTATTTGAGGATTT & \\
\hline
\end{tabular}

Analysis of exon/intron structure of $\boldsymbol{C b c y t b}$ : To investigate whether Cbcytb contains introns that may potentially be involved in $\mathrm{Q}_{\mathrm{O}} \mathrm{I}$ resistance as have been shown in other fungi (Grasso et al, 2006; Hily et al, 2011; Luo et al, 2010), six C. beticola isolates (1-18, 11-24, 1214, 12-82, 12-84, and 14-16; Table 3) were grown in liquid cultures as described above. Total RNA was isolated from 4-day-old mycelia using the RNeasy Plant Mini kit (Qiagen, Germantown, MD) following the manufacturer's instructions that included an on-column DNAse treatment (Qiagen). Total RNA $(0.5 \mu \mathrm{g})$ and primers 718 and 719 (Table 2) designed on the predicted Cbcytb coding region were used for RT-PCR using the SuperScript III One-Step RTPCR System with Platinum Taq DNA Polymerase (Invitrogen) according to the manufacturer's instructions. No reverse transcriptase (NRT) and no template (NT) controls were included for 
each sample during every PCR experiment. PCR amplicons were sequenced directly (McLab). Consensus sequences were generated and compared to genomic DNA sequences using Vector NTI (Invitrogen) software.

Table 2. Sensitivity of French and Italian Cercospora beticola populations to pyraclostrobin

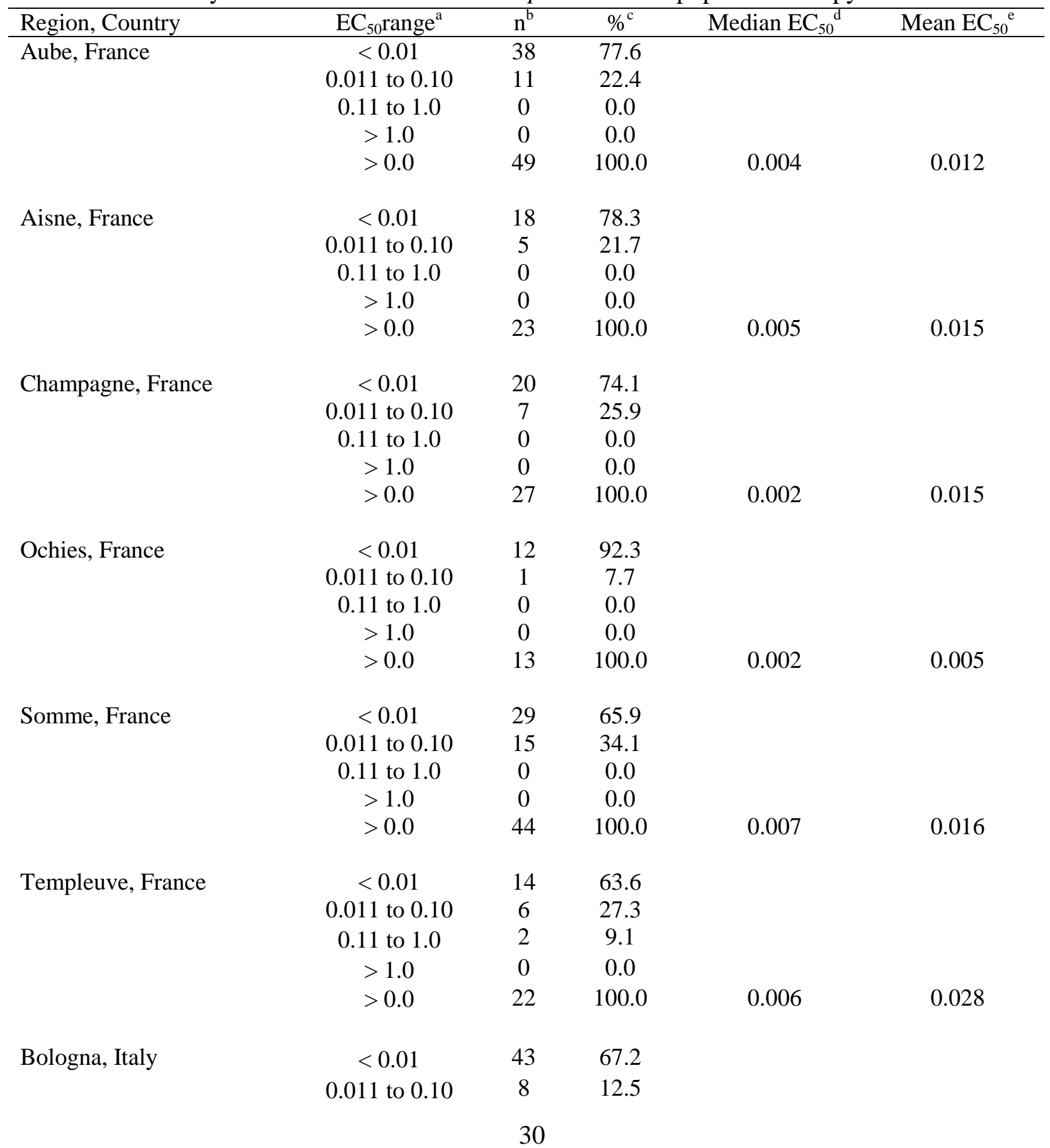


Table 2. Sensitivity of French and Italian Cercospora beticola populations to pyraclostrobin (continued)

\begin{tabular}{|c|c|c|c|c|c|}
\hline Region, Country & $\mathrm{EC}_{50} \mathrm{range}^{\mathrm{a}}$ & $\mathrm{n}^{\mathrm{b}}$ & $\%^{\mathrm{c}}$ & Median $\mathrm{EC}_{50}{ }^{\mathrm{d}}$ & Mean $\mathrm{EC}_{50}{ }^{\mathrm{e}}$ \\
\hline & 0.11 to 1.0 & 4 & 6.3 & & \\
\hline & $>1.0$ & 9 & 14.1 & & \\
\hline & $>0.0$ & 64 & 100.0 & 0.005 & 0.171 \\
\hline \multirow[t]{5}{*}{ Ferrara, Italy } & $<0.01$ & 32 & 52.5 & & \\
\hline & 0.011 to 0.10 & 12 & 19.7 & & \\
\hline & 0.11 to 1.0 & 4 & 6.6 & & \\
\hline & $>1.0$ & 13 & 21.3 & & \\
\hline & $>0.0$ & 61 & 100.0 & 0.009 & 0.267 \\
\hline \multirow[t]{5}{*}{ Rovigo, Italy } & $<0.01$ & 8 & 32.0 & & \\
\hline & 0.011 to 0.10 & 8 & 32.0 & & \\
\hline & 0.11 to 1.0 & 0 & 0.0 & & \\
\hline & $>1.0$ & 9 & 36.0 & & \\
\hline & $>0.0$ & 25 & 100.0 & 0.052 & 0.377 \\
\hline \multirow[t]{5}{*}{ Venezia, Italy } & $<0.01$ & 9 & 22.5 & & \\
\hline & 0.011 to 0.10 & 6 & 15.0 & & \\
\hline & 0.11 to 1.0 & 6 & 15.0 & & \\
\hline & $>1.0$ & 19 & 47.5 & & \\
\hline & $>0.0$ & 40 & 100.0 & 0.715 & 0.566 \\
\hline \multirow[t]{5}{*}{ Bologna, Italy ${ }^{\mathrm{f}}$} & $<0.01$ & 201 & 40.4 & & \\
\hline & 0.011 to 0.10 & 104 & 20.9 & & \\
\hline & 0.11 to 1.0 & 31 & 6.2 & & \\
\hline & $>1.0$ & 162 & 32.5 & & \\
\hline & $>0.0$ & 498 & 100.0 & 0.041 & 0.368 \\
\hline
\end{tabular}

${ }^{\mathrm{a}} \mathrm{EC}_{50}$ values $\left(\mu \mathrm{g} \mathrm{ml}^{-1}\right)$ were calculated for pyraclostrobin as described by Secor and Rivera (2012) and placed in ranges for each location.

${ }^{\mathrm{b}}$ Number of isolates in $\mathrm{EC}_{50}$ range for location.

${ }^{\mathrm{c}}$ Percentage of isolates in $\mathrm{EC}_{50}$ range for specified location.

${ }^{\mathrm{d}}$ Median $\mathrm{EC}_{50}$ values $\left(\mu \mathrm{g} \mathrm{ml}^{-1}\right)$ for all isolates collected for specified location.

${ }^{\mathrm{e}}$ Mean $\mathrm{EC}_{50}$ values $\left(\mu \mathrm{g} \mathrm{ml}^{-1}\right)$ for all isolates collected for specified location.

${ }^{\mathrm{f}}$ Isolates collected from naturally-infested research plots in Bologna, Italy.

Microsatellite analysis of selected $Q_{0} I$-sensitive and -resistant isolates: The genetic

background of selected $C$. beticola isolates were assessed using the microsatellite primer set

SSRCb3 (Groenewald et al, 2007) as described (Bolton et al, 2012b). Briefly, PCR

amplifications were carried out using the GoTaq Flexi DNA Polymerase kit (Promega) in a total volume of $20 \mu \mathrm{l}$ containing $1 \mathrm{X}$ Clear GoTaq Flexi Buffer, $1.5 \mathrm{mM} \mathrm{MgCl} 2,0.2 \mathrm{mM}$ of each 
deoxynucleotide triphosphate, $0.2 \mu \mathrm{M}$ of each primer, $1.0 \mathrm{U}$ of GoTaq DNA polymerase, and $\sim 25 \mathrm{ng}$ of genomic DNA. The PCR protocol was an initial denaturation at $94^{\circ} \mathrm{C}$ for $5 \mathrm{~min}$, followed by 40 cycles of $94^{\circ} \mathrm{C}$ for $20 \mathrm{~s}, 55^{\circ} \mathrm{C}$ for $20 \mathrm{~s}$, and $72^{\circ} \mathrm{C}$ for $30 \mathrm{~s}$. A final seven min elongation step at $72^{\circ} \mathrm{C}$ was included. Separation of labeled DNA fragments was performed by McLab using a Genetic Analyzer 3730xl (Applied Biosystems, Foster City, CA). Fragment size was determined using Peak Scanner Software (Version 1.0; Applied Biosystems). Isolates with the same microsatellite fragment size were considered clones.

\section{Development of PCR primers to discriminate $Q_{0} I$-resistant and $Q_{0} I$-sensitive}

isolates: Molecular detection of $\mathrm{Q}_{\mathrm{O}} \mathrm{I}$ resistance was determined using a mismatch amplification mutation assay (MAMA; (Cha et al, 1992; Siah et al, 2010). Primers (Table 1) were designed with a mismatch on the penultimate nucleotide of the 3' end of the forward primer, in which the ultimate nucleotide was at the point mutation position of codon 143 of Cbcytb. The primer set used to amplify a $613 \mathrm{bp}$ amplicon in $\mathrm{Q}_{\mathrm{O}} \mathrm{I}$-sensitive strains was forward primer 692, which harbored a mismatch of $\mathrm{T}$ instead of $\mathrm{G}$ at nucleotide 427 , and the reverse primer 694 . The primer set used to amplify a $381 \mathrm{bp}$ amplicon in resistant strains was the forward primer 695 , which contained a mismatch of $\mathrm{T}$ instead of $\mathrm{G}$ at nucleotide position 427, and the reverse primer 696 . Therefore, the sensitive primer set 692/694 resulted in a single nucleotide mismatch on sensitive strains and a double nucleotide mismatch on the resistant strains and vice versa for the resistant primer set 695/696. Molecular discrimination between $\mathrm{Q}_{\mathrm{O}} \mathrm{I}-\mathrm{sensitive}$ and -resistant isolates was tested using a gradient of $\mathrm{MgCl}_{2}$ concentrations (1.0 to $4.0 \mathrm{mM}$ ) and PCR annealing

temperatures $\left(45.0\right.$ to $\left.65.0^{\circ} \mathrm{C}\right)$ using DNA from $C b c y t b$ sequencing experiments described above or isolated from mycelia scraped from the surface of V8-medium plates described above. In the latter case, DNA was isolated using the DNeasy DNA extraction kit (Qiagen) following the 
manufacturer's instructions. The optimized PCR reaction conditions for discrimination between QOI-sensitive and -resistant isolates were carried out using the GoTaq Flexi DNA Polymerase kit (Promega) in a total volume of $25 \mu$ l containing $5 \mathrm{X}$ Green GoTaq Flexi Buffer, $2.5 \mathrm{mM} \mathrm{MgCl}$, $0.2 \mathrm{mM}$ of each deoxynucleotide triphosphate, $0.4 \mu \mathrm{M}$ of each primer, $1.25 \mathrm{U}$ of GoTaq DNA polymerase, and $10 \mathrm{ng}$ of genomic DNA. The PCR protocol was an initial denaturation at $94^{\circ} \mathrm{C}$ for $3 \mathrm{~min}$, followed by 36 cycles of $94^{\circ} \mathrm{C}(30 \mathrm{~s}), 64^{\circ} \mathrm{C}(30 \mathrm{~s})$, and $72^{\circ} \mathrm{C}(30 \mathrm{~s})$. A final elongation step at $72^{\circ} \mathrm{C}(5 \mathrm{~min})$ was included. PCR products were visualized on $1.5 \%$ ethidium bromidestained agarose gels. To assess the sensitivity of each primer set, template DNA isolated from the QOI-sensitive isolate 9-4 and the $\mathrm{Q}_{\mathrm{O}} \mathrm{I}$-resistant isolate 6-65 was diluted in a 2X-dilution series from $50.0 \mathrm{ng}$ to $1.5 \mathrm{pg}$.

Table 3. Sub-set of Cercospora beticola isolates used in this study

\begin{tabular}{|c|c|c|c|c|c|}
\hline & & Pyraclostrobin & Amino acid at codon & SSR allele size & \\
\hline Isolate & Region, Country & $\mathrm{EC}_{50}{ }^{\mathrm{a}}$ & 143 in $C b c y t b$ & $(b p)^{b}$ & Accession $\#^{\mathrm{c}}$ \\
\hline $1-14$ & Aube, FR & 0.014 & $\mathrm{G}$ & 270 & -- \\
\hline $1-16$ & Aube, FR & 0.064 & G & 270 & -- \\
\hline $1-17$ & Aube, FR & 0.077 & G & 270 & -- \\
\hline $1-18$ & Aube, FR & 0.001 & $\mathrm{G}$ & 303 & JQ360625 \\
\hline $1-39$ & Aube, FR & 0.063 & $\mathrm{G}$ & 270 & -- \\
\hline $1-55$ & Aube, FR & 0.024 & G & 270 & -- \\
\hline $1-59$ & Aube, FR & 0.008 & G & 270 & -- \\
\hline $1-64$ & Aisne, FR & 0.008 & $\mathrm{G}$ & 270 & -- \\
\hline $1-79$ & Aisne, FR & 0.060 & G & 270 & -- \\
\hline $1-93$ & Aisne, FR & 0.100 & G & 269 & -- \\
\hline $2-14$ & Champagne, FR & 0.006 & G & 319 & -- \\
\hline $2-17$ & Champagne, FR & 0.077 & G & 272 & -- \\
\hline $2-40$ & Champagne, FR & 0.057 & G & 333 & -- \\
\hline $2-57$ & Somme, FR & 0.005 & G & 302 & -- \\
\hline $2-59$ & Somme, FR & 0.003 & G & 302 & -- \\
\hline $2-61$ & Somme, FR & 0.009 & G & 333 & -- \\
\hline $2-66$ & Somme, FR & 0.053 & G & 270 & -- \\
\hline $2-67$ & Somme, FR & 0.019 & G & 271 & -- \\
\hline $2-75$ & Somme, FR & 0.006 & G & 302 & -- \\
\hline
\end{tabular}


Table 3. Sub-set of Cercospora beticola isolates used in this study (continued)

\begin{tabular}{|c|c|c|c|c|c|}
\hline & & Pyraclostrobin & Amino acid at codon & SSR allele size & \\
\hline Isolate & Region, Country & $\mathrm{EC}_{50}{ }^{\mathrm{a}}$ & 143 in Cbcytb & $(b p)^{b}$ & Accession $\#^{\mathrm{c}}$ \\
\hline $2-78$ & Somme, FR & 0.001 & $\mathrm{G}$ & 302 & -- \\
\hline $2-88$ & Somme, FR & 0.022 & G & 330 & -- \\
\hline $2-92$ & Somme, FR & 0.009 & $\mathrm{G}$ & 330 & -- \\
\hline $3-39$ & Ochies, FR & 0.001 & G & 245 & -- \\
\hline $4-7$ & Templeuve, FR & 0.224 & $\mathrm{G}$ & 240 & -- \\
\hline $4-14$ & Templeuve, FR & 0.001 & G & 323 & JQ360626 \\
\hline $4-22$ & Templeuve, FR & 0.001 & $\mathrm{G}$ & 241 & -- \\
\hline $4-24$ & Templeuve, FR & 0.076 & G & 241 & -- \\
\hline $4-27$ & Templeuve, FR & 0.164 & $\mathrm{G}$ & 241 & -- \\
\hline $5-1$ & Venezia, IT & 0.005 & $\mathrm{G}$ & 302 & -- \\
\hline $5-3$ & Venezia, IT & 0.394 & A & 301 & -- \\
\hline $5-30$ & Venezia, IT & 0.845 & A & 301 & -- \\
\hline $5-33$ & Venezia, IT & 0.539 & A & 301 & -- \\
\hline $5-41$ & Rovigo, IT & 39.385 & A & 244 & -- \\
\hline $6-5$ & Venezia, IT & 10.000 & A & 269 & JQ360628 \\
\hline $6-73$ & Ferrara, IT & 56.644 & A & 243 & -- \\
\hline $7-21$ & Ferrara, IT & 1.803 & A & 301 & -- \\
\hline $7-45$ & Bologna, IT & 5.328 & A & 302 & -- \\
\hline $7-60$ & Bologna, IT & 6.956 & A & 302 & -- \\
\hline $7-61$ & Bologna, IT & 0.344 & A & 240 & -- \\
\hline $8-6$ & Bologna, IT & 8.500 & A & 244 & -- \\
\hline $8-32$ & Bologna, IT & 0.735 & A & 301 & -- \\
\hline $8-39$ & Bologna, IT & 0.406 & $\mathrm{G}$ & 270 & -- \\
\hline $9-4$ & Bologna, IT & 0.027 & G & 302 & -- \\
\hline $9-56$ & Bologna, IT & 0.798 & G & 268 & -- \\
\hline $9-62$ & Bologna, IT & 60.223 & A & 302 & -- \\
\hline $10-11$ & Bologna, IT & 0.042 & $\mathrm{G}$ & 270 & -- \\
\hline $10-52$ & Bologna, IT & 0.362 & A & 301 & -- \\
\hline $11-24$ & Bologna, IT & 24.407 & A & 243 & -- \\
\hline $12-5$ & Bologna, IT & 4.658 & A & 243 & -- \\
\hline $12-14$ & Bologna, IT & 0.065 & G & 270 & -- \\
\hline $12-20$ & Bologna, IT & 43.012 & A & 302 & JQ360627 \\
\hline $12-25$ & Bologna, IT & 0.722 & A & 301 & -- \\
\hline $12-49$ & Bologna, IT & 0.211 & $\mathrm{G}$ & 301 & -- \\
\hline $12-65$ & Bologna, IT & 34.413 & A & 300 & -- \\
\hline $12-74$ & Bologna, IT & 38.033 & A & 302 & -- \\
\hline $12-82$ & Bologna, IT & 0.062 & $\mathrm{G}$ & 302 & -- \\
\hline $12-84$ & Bologna, IT & 13.982 & A & 300 & -- \\
\hline $12-86$ & Bologna, IT & 8.397 & A & 302 & -- \\
\hline $12-93$ & Bologna, IT & 6.343 & A & 302 & -- \\
\hline
\end{tabular}


Table 3. Sub-set of Cercospora beticola isolates used in this study (continued)

\begin{tabular}{cccccc}
\hline Isolate & Region, Country & $\begin{array}{c}\text { Pyraclostrobin Amino acid at codon } \\
\mathrm{EC}_{50}{ }^{\mathrm{a}}\end{array}$ & $\begin{array}{c}\text { SSR allele size } \\
(\mathrm{bp})^{\mathrm{b}}\end{array}$ & Accession \# $^{\mathrm{c}}$ \\
\hline $12-94$ & Bologna, IT & 0.828 & $\mathrm{~A}$ in & 301 & - \\
$13-18$ & Bologna, IT & 13.325 & $\mathrm{~A}$ & 270 & - \\
$13-32$ & Bologna, IT & 3.284 & $\mathrm{~A}$ & 355 & - \\
$13-42$ & Bologna, IT & 41.380 & $\mathrm{~A}$ & 355 & - \\
$13-61$ & Bologna, IT & 0.199 & $\mathrm{G}$ & 301 & - \\
$13-63$ & Bologna, IT & 0.311 & $\mathrm{G}$ & 330 & - \\
$14-16$ & Bologna, IT & 0.001 & $\mathrm{G}$ & 244 & - \\
$14-25$ & Bologna, IT & 17.470 & $\mathrm{~A}$ & 242 & - \\
$14-35$ & Bologna, IT & 12.959 & $\mathrm{~A}$ & 269 & - \\
\hline
\end{tabular}

${ }^{\mathrm{a}} \mathrm{EC}_{50}$ values $\left(\mu \mathrm{g} \mathrm{ml}^{-1}\right)$ were calculated for pyraclostrobin as previously described (Secor and Rivera, 2012).

${ }^{\mathrm{b}}$ SSR allele sizes using primer set SSRCb3 (Groenewald et al, 2007).

${ }^{\mathrm{c}}$ GenBank accession \# for Cbcytb sequence and deduced amino acid sequence.

\section{Results}

Survey of European Cercospora beticola isolates sensitivity to pyraclostrobin: Eight hundred sixty six isolates harvested from sugar beet fields in France and Italy were assed for in vitro sensitivity to the $\mathrm{Q}_{\mathrm{O}} \mathrm{I}$ fungicide pyraclostrobin (Table 2). All isolates collected in France $(\mathrm{n}=178)$ had $\mathrm{EC}_{50}$ values $<0.10$ with the exception of two isolates harvested in Templeuve that exhibited $\mathrm{EC}_{50}$ values from 0.11 to $1.0 \mu \mathrm{g} \mathrm{ml}^{-1}$ (Table 2). Median $\mathrm{EC}_{50}$ values were similar among the French populations, which ranged from 0.002 to $0.007 \mu \mathrm{g} \mathrm{ml}^{-1}$ while mean $\mathrm{EC}_{50}$ values ranged from 0.005 to $0.028 \mu \mathrm{g} \mathrm{ml}^{-1}$ (Table 2).

In contrast, Italian populations collected from commercial fields exhibited larger variation in median (0.005 to $\left.0.715 \mu \mathrm{g} \mathrm{ml}^{-1}\right)$ and mean $\left(0.171\right.$ to $\left.0.566 \mu \mathrm{g} \mathrm{ml}^{-1}\right) \mathrm{EC}_{50}$ values (Table 2). All Italian populations from commercial fields contained 14\% or more isolates with $\mathrm{EC}_{50}$ values $>1.0 \mu \mathrm{g} \mathrm{ml}^{-1}$ (Table 2). Isolates $(\mathrm{n}=498)$ were also harvested from naturally-infested research plots near Bologna, Italy (Table 2). 32\% of this population consisted of isolates with 
$\mathrm{EC}_{50}$ values $>1.0 \mu \mathrm{g} \mathrm{ml}^{-1}$ (Table 2). Several isolates were chosen for further study, which included calculation of their $\mathrm{EC}_{50}$ values up to $100.0 \mu \mathrm{g} \mathrm{ml}^{-1}$ (Table 3).

Cbcytb cloning and sequence analysis: Using a previously published partial fragment of Cbcytb as a starting point (Malandrakis et al, 2006), we used a primer walking strategy to clone $1035 \mathrm{bp}$ on the 5 ' end of the fragment, which included $841 \mathrm{bp}$ upstream of the predicted start codon. In addition, $655 \mathrm{bp}$ were identified on the 3' end of the fragment. RT-PCR confirmed that no introns were identified in any of the isolates tested. Therefore, the full-length $C b c y t b$ coding sequence was 1,161 bp in length. Top BLASTP hits of the deduced 386-amino acid C. beticola cytochrome b protein sequence were to cytochrome b from Mycosphaerella graminicola (Evalue $=0.0 ; 94 \%$ identity, $98 \%$ similarity $),$ Phialocephala subalpina $($ E-value $=0.0 ; 91 \%$ identity, 97\% similarity), Peltigera membranacea $($ E-value $=0.0 ; 90 \%$ identity, 96\% similarity), P. malacea $($ E-value $=0.0 ; 90 \%$ identity, 96\% similarity), and Venturia inaequalis $($ E-value $=$ $0.0 ; 89 \%$ identity, $96 \%$ similarity).

Because resistance to fungicides can be related to over-expression of the gene encoding the fungicide-targeted enzyme (Bolton et al, 2012a), we sequenced Cbcytb flanking sequence in addition to the entire $C b c y t b$ coding sequence to determine whether mutations in promoter regions related to fungicide resistance. In total, the $C b c y t b$ gene and flanking sequence data was obtained from 59 isolates with $\mathrm{EC}_{50}$ values ranging from 0.001 to $60.223 \mu \mathrm{g} \mathrm{ml}^{-1}$. With regard to the $C b c y t b$ coding region, two nucleotide haplotypes were identified which encoded either a glycine or an alanine at codon 143 . Without exception, isolates with $\mathrm{EC}_{50}$ values greater than 1.0 $\mu \mathrm{g} \mathrm{ml}^{-1}$ harbored a point mutation at nucleotide position 428 that encoded a G143A mutation (Table 3). Therefore, isolates harboring the G143A mutation were categorized as QoI-resistant. 
Likewise, all isolates with $\mathrm{EC}_{50}$ values less than $\sim 0.2 \mu \mathrm{g} \mathrm{ml}^{-1}$ exhibited the wild-type $C b c y t b$ sequence and were categorized as $\mathrm{Q}_{\mathrm{O}} \mathrm{I}$-sensitive (Table 3). Isolates with $\mathrm{EC}_{50}$ values between 0.3 and $0.8 \mu \mathrm{g} \mathrm{ml}^{-1}$ were obtained that contained either the wild-type sequence or G143A mutation (Table 3). Analysis of sequence trace files did not indicated evidence of heteroplasmy in these isolates. No isolates collected in France harbored the G143A mutation. Besides this mutation, an insertion/deletion (indel) was found 25 nucleotides downstream of the translational stop codon. The occurrence of this indel did not appear to relate to $\mathrm{Q}_{\mathrm{O}} \mathrm{I}$ resistance, as it was found in $\mathrm{Q}_{\mathrm{O}} \mathrm{I}-$ sensitive and -resistant isolates. Representatives of the four Cbcytb sequences identified in this study have been deposited in GenBank under accession numbers JQ360625 through JQ360628.

Genetic diversity of selected QoI-resistant isolates: A SSR primer set was utilized that differentiated 17 alleles from selected $Q_{\mathrm{O}} \mathrm{I}-$ sensitive and -resistant isolates (Table 3). Although sample sizes were too small to adequately assess genetic diversity at each sampling site location, 13 and 9 SSR haplotypes were identified France and Italy, respectively. In total, there were eight SSR haplotypes represented in all selected QoI-resistant isolates (Table 3).

\section{Molecular discrimination of $\mathbf{Q}_{0} \mathrm{I}$-sensitive and -resistant isolates: Primers were} designed to differentiate $\mathrm{Q}_{\mathrm{O}} \mathrm{I}$-sensitive and -resistant isolates based on the point mutation at nucleotide position 428 encoding the G143A mutation. PCR conditions were validated using a gradient of $\mathrm{MgCl}_{2}$ concentrations and PCR annealing temperatures. For every isolate tested, two PCR reactions allowed discrimination between $\mathrm{Q}_{\mathrm{O}} \mathrm{I}$-sensitive and -resistant isolates where a 613 bp product using the 692/694 primer set combined with no amplification product from the 695/696 primer set was indicative of a sensitive strain (Fig. 3A). Likewise, a 381 bp amplicon using the 695/696 primer set and no amplification with 692/694 indicated of a QoI-resistant 
strain (Fig. 3A). No isolate produced amplicons from both primer sets. The 692/694 primer set produced a visible $613 \mathrm{bp}$ amplicon using $50.0 \mathrm{ng}$ to approximately $24.0 \mathrm{pg}$ of DNA as template in PCR reactions (Fig. 3B). The 695/696 primer set produced a visible 381 bp amplicon using $50.0 \mathrm{ng}$ to approximately $12.0 \mathrm{pg}$ of DNA as template in PCR reactions (Fig. 3B).

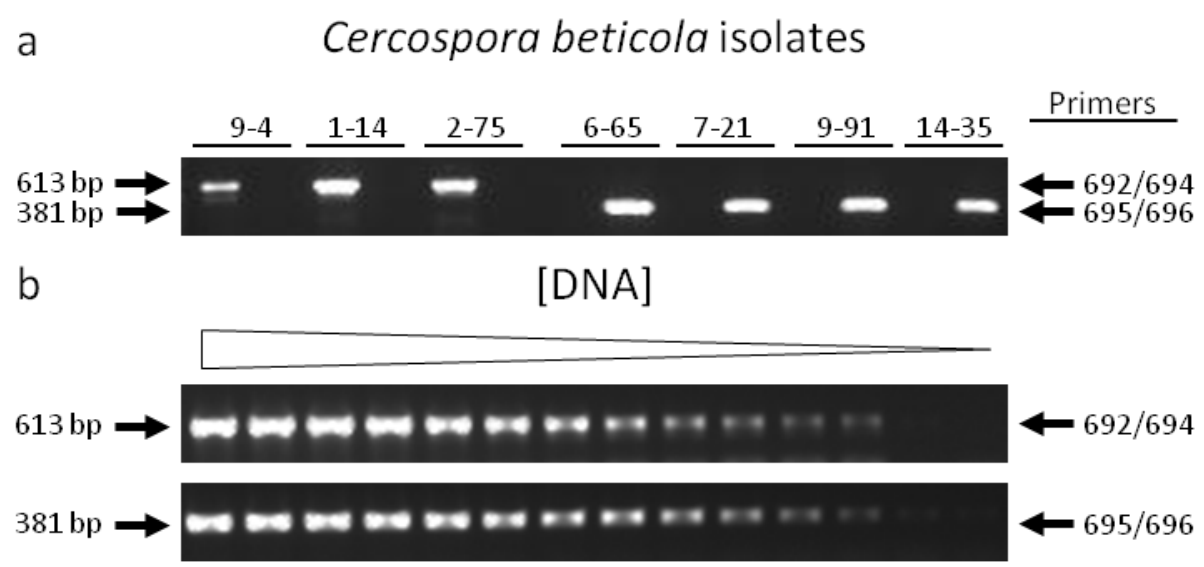

Figure 3. Identification of Cercospora beticola isolates with QoI-resistance. A) Sub-set of $C$. beticola isolates screened with PCR using the 692/694 (MAMA-sensitive) and 695/696 (MAMA-resistant) primer sets. Isolates 9-4, 1-14, and 2-75 are QoI-sensitive and isolates 6-65, 7-21, 9-91, and 14-35 are $\mathrm{Q}_{\mathrm{O}} \mathrm{I}-\mathrm{resistant.}$ B) Sensitivity of 695/696 and 692/694 primer sets. Template DNA isolated from QoI-sensitive isolate 9-4 and QoI-resistant isolate 6-65 was diluted in a $2 X$-dilution series from $50.0 \mathrm{ng}$ to $1.5 \mathrm{pg}$ for PCR reactions. Dilutions from $50.0 \mathrm{ng}$ to approximately $6.0 \mathrm{pg}$ shown here.

\section{Discussion}

$\mathrm{Q}_{\mathrm{O}} \mathrm{Is}$ represent one of the most important fungicide classes in agriculture. However, reports of control failures due to $\mathrm{Q}_{\mathrm{O}} \mathrm{I}$ resistance development have been described for an increasing number of pathosystems in recent years (Lesniak et al, 2011; Pasche et al, 2005; 
Sierotzki et al, 2007; Sierotzki et al, 2000). In this study, $\mathrm{EC}_{50}$ values to the $\mathrm{Q}_{0} \mathrm{I}$ fungicide pyraclostrobin were identified in 866 C. beticola isolates collected from the sugar beet growing regions of France and Italy. No resistant phenotypes could be found in French sugar beet growing regions, but isolates with $\mathrm{EC}_{50}$ values greater than $1.0 \mu \mathrm{g} \mathrm{ml}^{-1}$ were found in Italy. To our knowledge, this is the first report of the identification of $C$. beticola isolates with reduced sensitivity to $\mathrm{Q}_{0} \mathrm{I}$ fungicides in Europe. Azoxystrobin was first registered in 2009 in France, followed by trifloxystrobin and pyraclostrobin in 2010 (Marc Richard-Molard, personal communication). In Italy, azoxystrobin, trifloxystrobin, and pyraclostrobin were first used to control CLS in 1999, 2002, and 2009, respectively (F. Cioni, personal communication). Therefore, resistant $C$. beticola populations were detected 11 years after the first $\mathrm{Q}_{\mathrm{O}} \mathrm{I}$ fungicide was registered for use on sugar beet in Italy. Malandrakis et al, (2011) recently characterized pyraclostrobin resistance levels of isolates harvested from sugar beet fields in northern Greece, but no resistant phenotypes were identified in that region despite use of $\mathrm{Q}_{\mathrm{O}} \mathrm{I}$ fungicides to control CLS since 2003.

Point mutations in the cytochrome $b$ gene that encode an amino acid substitution are the predominant mechanism for reduced sensitivity to $\mathrm{Q}_{\mathrm{O}} \mathrm{I}$ fungicides in plant pathogenic fungi. To investigate whether this type of mechanism explains the reduced sensitivity to $\mathrm{Q}_{\mathrm{O}} \mathrm{I}$ fungicides, we cloned the full-length $C$. beticola cytochrome $b(C b c y t b)$ gene and carried out sequence analysis from isolates with varying sensitivity to pyraclostrobin. All isolates tested that exhibited an $\mathrm{EC}_{50}$ value greater than $1.0 \mu \mathrm{g} \mathrm{ml}^{-1}$ harbored the G143A mutation. This is the first report of QoI resistance associated with the G143A mutation in isolates of $C$. beticola. Isolates with the G143A mutation had $\mathrm{EC}_{50}$ values ranging from $\sim 0.3$ to over $60 \mu \mathrm{g} \mathrm{ml}^{-1}$ (Table 3). This range in $\mathrm{Q}_{\mathrm{O}} \mathrm{I}$ resistance phenotypes perhaps suggests that other mechanisms are involved in $\mathrm{Q}_{\mathrm{O}} \mathrm{I}$ tolerance 
in C. beticola. For example, the G143A mutation in conjunction with over expression of a major facilitator drug transporter was shown to be involved with $\mathrm{Q}_{\mathrm{O}} \mathrm{I}$ resistance in the wheat pathogen Mycosphaerella graminicola (Roohparvar et al, 2008). Alternative respiration pathways have also been shown to be involved with $\mathrm{Q}_{\mathrm{O}} \mathrm{I}$ resistance (Amand et al, 2003). Therefore, despite the clear association between high $\mathrm{EC}_{50}$ values and the $\mathrm{G} 143 \mathrm{~A}$ mutation found in this study, other factors may be involved with $\mathrm{Q}_{\mathrm{O}} \mathrm{I}$ resistance in C. beticola.

All isolates with $\mathrm{EC}_{50}$ values greater than $1.0 \mu \mathrm{g} \mathrm{ml}^{-1}$ harbored a G143A mutation in Cbcytb. However, several isolates with $\mathrm{EC}_{50}$ values between 0.3 and $0.8 \mu \mathrm{g} \mathrm{ml}^{-1}$ were obtained that contained either the wild-type sequence or G143A mutation (Table 3). Although sequencing trace files did not indicate evidence of heteroplasmy (discussed below), resistant and sensitive alleles may coexist in the same isolate that are below the levels of detection from trace file analysis and may be involved in the elevated $\mathrm{EC}_{50}$ values of isolates with wild-type $C b c y t b$ sequence. Alternatively, exposure to other fungicides applied in the field prior to isolate collection may have affected germination in vitro and subsequently influenced $\mathrm{EC}_{50}$ calculations. Since this is a biological assay, biological variability is unavoidable. In general, our results suggest that isolates with $\mathrm{EC}_{50}$ values of $\sim 0.3 \mu \mathrm{g} \mathrm{ml}^{-1}$ or greater are likely a cause for concern as they may harbor the G143A mutation.

Detection of QoI-resistance via the G143A mutation has been reported in several pathosystems (Fontaine et al, 2009; Fraaije et al, 2002; Sierotzki et al, 2000). The MAMA primer set developed here was very sensitive, allowing for the differentiation of $\mathrm{Q}_{\mathrm{O}} \mathrm{I}$-sensitivity in isolates using as little as $25 \mathrm{pg}$ of template DNA. Moreover, this cost-effective technique can be scaled up for high-throughput detection of $\mathrm{Q}_{\mathrm{O}} \mathrm{I}$-resistance, an important feature for 
laboratories that screen many isolates upon disease onset during the growing season. Although we did not detect both the wild type and mutated G143A allele in any one isolate tested, a mixed population of mitochondria with and without the G143A mutation may exist in heteroplasmic strains. Heteroplasmic isolates containing $\mathrm{Q}_{\mathrm{O}} \mathrm{I}-$ sensitive and $\mathrm{Q}_{\mathrm{O}} \mathrm{I}-\mathrm{resistant}$ mitochondria have been described (Fraaije et al, 2002; Zheng et al, 2000). Since we collected samples after the final QoI fungicide applications in the 2010 growing season, strong selection pressure for the G143A allele may have already occurred. Similarly, application of azoxystrobin caused a pronounced selection for the $\mathrm{Q}_{0} \mathrm{I}$-resistant allele in Blumeria graminis f. sp. tritici (Fraaije et al, 2002).

The detection of $\mathrm{Q}_{\mathrm{O}} \mathrm{I}$ resistance and the G143A mutation in several sugar beet growing regions in Italy raises questions concerning the origin of resistance in $C$. beticola. One possible explanation is that resistance arose in an isolate and repeated fungicide applications selected for the resistant genotype, which subsequently spread to other regions in Italy. Alternatively, resistance could occur independently in several genetic backgrounds across several locations. The results of our study suggest the latter scenario most likely explains the development of $\mathrm{Q}_{\mathrm{O}} \mathrm{I}-$ resistance in C. beticola. First, resistant isolates were found in a variety of sugar beet growing regions in Italy. Cercospora beticola is not known for large-scale inoculum movement across wide geographical areas as been shown for other plant pathogens such as Puccinia triticina (Bolton et al, 2008), so it would appear unlikely that $\mathrm{Q}_{\mathrm{O}} \mathrm{I}-$ resistant inoculum found throughout the geographical areas sampled in this study originated from a single location. Secondly, several SSR haplotypes were identified in QoI-resistant isolates. SSR markers are useful in assessing genetic diversity and the finding that several SSR haplotypes can be distinguished among the subset of $\mathrm{Q}_{\mathrm{O}} \mathrm{I}$-resistant isolates tested in this study suggests that resistance developed independently at several geographical regions in C. beticola. Similarly, Torriani et al, (2009) 
found the G143A mutation in 24 different $M$. graminicola mtDNA haplotypes across several geographic locations in Europe. Kim et al, (2003) noted that $\mathrm{Q}_{\mathrm{O}} \mathrm{I}$ resistance in Pyriculariagrisea occurred in five genetic backgrounds.

Studies of the genetic structure of $C$. beticola populations have shown high degrees of genetic variation (Bolton et al, 2012b; Groenewald et al, 2008; Moretti et al, 2006). Genetic diversity is typically more prevalent in populations that undergo sexual reproduction than those reproducing asexually (Milgroom, 1996). Indeed, pathogen populations that undergo regular sexual recombination pose a greater risk of defeating resistance genes than strictly asexual pathogens (McDonald and Linde, 2002), which is also likely to be involved in the development of fungicide resistance. Nonetheless, despite a level of genetic diversity found in C. beticola populations suggestive of sexual recombination, no teleomorph has been described for $C$. beticola. The identification of the teleomorph would help answer the question as to whether fungicide resistance development is facilitated by sexual reproduction in this pathosystem.

Fungicides continue to be an important tool for leaf spot disease management. Intensive use of $\mathrm{Q}_{\mathrm{O}} \mathrm{I}$ fungicides over several years likely led to the development and expansion of $\mathrm{Q}_{\mathrm{O}} \mathrm{I}-$ resistant populations in C. beticola. Economic constraints as well as potential and perceived environmental concerns from pesticide over-application favor judicious use of fungicides. In some locations, growers may apply reduced fungicide rates in attempts to decrease inputs and increase profits. However, reduced fungicide concentrations may give a sub-lethal dose to a portion of a field population, which may effectively increase the frequency of mutation in a location and accelerate the evolution of fungicide resistance (Gressel, 2011).On the other hand, other studies show increased selection for fungicide resistance with increased fungicide dose 
(van den Bosch et al, 2011). Future studies directed towards the comparison of these fungicide application practices will need to be conducted to understand the role of fungicide rate in the evolution of fungicide resistance in C. beticola.

In conclusion, we identified European isolates with high $\mathrm{EC}_{50}$ values to pyraclostrobin, a $\mathrm{Q}_{\mathrm{O}} \mathrm{I}$ fungicide that is used extensively for CLS management. All isolates tested with high $\mathrm{EC}_{50}$ values exhibited the G143A substitution, a mutation well known to be involved with fungicide resistance in several pathosystems. Since $\mathrm{Q}_{\mathrm{O}} \mathrm{I}$ resistance appears to have occurred independently in multiple genetic backgrounds at several locations, careful fungicide management decisions will need to be made to ensure that this mutation does not become more widespread in other European sugar beet growing areas. Monitoring $\mathrm{Q}_{\mathrm{O}} \mathrm{I}$ resistance in a field may be especially important during the growing season when short fungicide application intervals are combined high CLS disease pressure, which demands a quick turnaround time to help guide the choice of fungicides to apply. Effective control of CLS requires an integrated approach involving crop rotation, planting CLS-tolerant varieties, and timely application of fungicides from several fungicide classes to minimize fungicide resistance development.

\section{References}

Altschul, S. F., Gish, W., Miller, W., Myers, E. W., and Lipman, D. J. 1990. Basic local alignment search tool. Journal of Molecular Biology 215:403-410.

Amand, O., Calay, F., Coquillart, L., Legat, T., Bodson, B., Moreau, J. M., and Maraite, H. 2003. First detection of resistance to $\mathrm{Q}_{\mathrm{O}} \mathrm{I}$ fungicides in Mycosphaerella graminicola on winter wheat in Belgium. Communications in Agricultural and Applied Biological Sciences 68:519. 
Banno, S., Yamashita, K., Fukumori, F., Okada, K., Uekusa, H., Takagaki, M., Kimura, M., and Fujimura, M. 2009. Characterization of Q $\mathrm{O} I$ resistance in Botrytis cinerea and identification of two types of mitochondrial cytochrome $b$ gene. Plant Pathology 58:120129.

Bartlett, D. W., Clough, J. M., Godwin, J. R., Hall, A. A., Hamer, M., and Parr-Dobrzanski, B. 2002. The strobilurin fungicides. Pest Management Science 58:649-662.

Bolton, M. D., Birla, K., Rivera-Varas, V., Rudolph, K., and Secor, G. A. 2012a. Characterization of CbCyp51 from field isolates of Cercospora beticola. Phytopathology 102:298-305 .

Bolton, M. D., Kolmer, J. A., and Garvin, D. F. 2008. Wheat leaf rust caused by Puccinia triticina. Molecular Plant Pathology 9:563-575.

Bolton, M. D., Secor, G. A., Rivera, V., Weiland, J. J., Rudolph, K., Birla, K., Rengifo, J., and Campbell, L. G. 2012b. Evaluation of the potential for sexual reproduction in field populations of Cercospora beticola from USA. Fungal Biology 116:511-521.

Cha, R. S., Zarbl, H., Keohavong, P., and Thilly, W. G. 1992. Mismatch amplification mutation assay (MAMA): application to the cH-ras gene. Genome Research 2:14-20.

Chin, K. M., Chavaillaz, D., Kaesbohrer, M., Staub, T., and Felsenstein, F. G. 2001. Characterizing resistance risk of Erysiphe graminis f.sp. tritici to strobilurins. Crop Protection 20:87-96. 
Daub, M. E., and Ehrenshaft, M. 2000. The photoactivated Cercospora toxin cercosporin: contributions to plant disease and fundamental biology. Annual Reviews in Phytopathology 38:461-490.

Fisher, N., and Meunier, B. 2008. Molecular basis of resistance to cytochrome $b c 1$ inhibitors. FEMS Yeast Research 8:183-192.

Fontaine, S., Remuson, F., Fraissinet-Tachet, L., Micoud, A., Marmeisse, R., and Melayah, D. 2009. Monitoring of Venturia inaequalis harbouring the $\mathrm{Q}_{\mathrm{O}} \mathrm{I}$ resistance G143A mutation in French orchards as revealed by PCR assays. Pest Management Science 65:74-81.

Fraaije, B. A., Butters, J. A., Coelho, J. M., Jones, D. R., and Hollomon, D. W. 2002. Following the dynamics of strobilurin resistance in Blumeria graminis f.sp. tritici using quantitative allele-specific real-time PCR measurements with the fluorescent dye SYBR Green I. Plant Pathology 51:45-54.

FRAC, 2011. FRAC list of plant pathogenic organisms resistant to disease control agents.

Garzón, C. D., Molineros, J. E., Yánez, J. M., Flores, F. J., del Mar Jiménez-Gasco, M., and Moorman, G. W. 2011. Sublethal doses of mefenoxam enhance pythium damping-off of geranium. Plant Disease 95:1233-1238.

Gisi, U., Sierotzki, H., Cook, A., and McCaffery, A. 2002. Mechanisms influencing the evolution of resistance to Qo inhibitor fungicides. Pest Management Science 58:859-867. 
Grasso, V., Palermo. S., Sierotzki, H., Garibaldi, A., and Gisi, U. 2006. Cytochrome $b$ gene structure and consequences for resistance to Qo inhibitor fungicides in plant pathogens. Pest Management Science 62:465-472.

Gressel, J. 2011. Low pesticide rates may hasten the evolution of resistance by increasing mutation frequencies. Pest Management Science 67:253-257.

Groenewald, M., Groenewald, J. Z., Linde, C. C., and Crous, P. W. 2007. Development of polymorphic microsatellite and single nucleotide polymorphism markers for Cercospora beticola (Mycosphaerellaceae). Molecular Ecology Notes 7:890-892.

Groenewald, M., Linde, C. C., Groenewald, J. Z., and Crous, P. W. 2008. Indirect evidence for sexual reproduction in Cercospora beticola populations from sugar beet. Plant Pathology $57: 25-32$

Hily, J-M., Singer, S. D., Villani, S. M., and Cox, K. D. 2011. Characterization of the cytochrome $b(c y t b)$ gene from Monilinia speciescausing brown rot of stone and pome fruit and its significance in the development of $\mathrm{Q}_{\mathrm{O}} \mathrm{I}$ resistance. Pest Management Science 67:385-396.

Kaiser, U., Kluth, C., and Märländer, B. 2010. Variety-specific epidemiology of Cercospora beticola Sacc. and consequences for threshold-based timing of fungicide application in sugar beet. Journal of Phytopathology 158:296-306.

Karaoglanidis, G. S., and Ioannidis, P. M. 2010. Fungicide resistance of Cercospora beticola in Europe, in: Lartey RT, Weiland JJ, Panella L, Crous PWW, C. E. (Eds), Cercospora leaf spot of sugar beet and related species. The American Phytopathological Society, St. Paul. 46 
Khan, J., Qi, A., and Khan, M. F. R. 2009. Fluctuations in number of Cercospora beticola conidia in relationship to environment and disease severity in sugar beet. Phytopathology 99:796-801.

Kim, Y. S., Dixon, E. W., Vincelli, P., and Farman, M. L. 2003. Field resistance to strobilurin (QoI) fungicides in Pyricularia grisea caused by mutations in the mitochondrial cytochrome b gene. Phytopathology 93:891-900.

Lesniak, K. E., Proffer, T. J., Beckerman, J. L., and Sundin, G. W. 2011. Occurrence of QoI resistance and detection of the G143A mutation in Michigan populations of Venturia inaequalis. Plant Disease 95:927-934.

Luo, C. X., Hu, M. J., Jin, X., Yin, L. F., Bryson, P. K., and Schnabel, G. 2010. An intron in the cytochrome $b$ gene of Monilinia fructicola mitigates the risk of resistance development to Q $\mathrm{I}$ fungicides. Pest Management Science 66:1308-1315.

Malandrakis, A., Markoglou, A., Nikou, D., Vontas, J., and Ziogas, B. 2006. Biological and molecular characterization of laboratory mutants of Cercospora beticola resistant to Qo inhibitors. European Journal of Plant Pathology 116:155-166.

Malandrakis, A. A., Markoglou, A. N., Nikou, D. C., Vontas, J. G., and Ziogas, B. N. 2011. Molecular diagnostic for detecting the cytochrome $b \mathrm{G} 143 \mathrm{~S}-\mathrm{Q}_{\mathrm{O}} \mathrm{I}$ resistance mutation in Cercospora beticola. Pesticide Biochemistry and Physiology 100:87-92.

McDonald, B. A., and Linde, C. 2002. Pathogen population genetics, evolutionary potential, and durable resistance. Annual Review of Phytopathology 40:349-379. 
Milgroom, M. G. 1996. Recombination and the multilocus structure of fungal populations. Annual Review of Phytopathology 34:457-477.

Moretti, M., Karaoglanidis, G., Saracchi, M., Fontana, A., and Farina, G. 2006. Analysis of genotypic diversity in Cercospora beticola Sacc. field isolates. Annals of Microbiology $56: 215-221$.

Pasche, J. S., Piche, L. M., and Gudmestad, N. C. 2005. Effect of the F129L mutation in Alternaria solani on fungicides affecting mitochondrial respiration. Plant Disease 89:269278.

Roohparvar, R., Mehrabi, R., Van Nistelrooy, J. G., Zwiers, L. H., and De Waard, M. A. 2008. The drug transporter MgMfs1 can modulate sensitivity of field strains of the fungal wheat pathogen Mycosphaerella graminicola to the strobilurin fungicide trifloxystrobin. Pest Management Science

Secor, G. A., and Rivera, V. V. 2012. Fungicide resistance assays for fungal plant pathogens, in: Bolton MD, Thomma BPHJ (Eds), Plant Fungal Pathogens: Methods and Protocols. Humana Press, New York, pp. 385-392.

Secor, G. A., Rivera, V. V., Khan, M. F. R., and Gudmestad, N. C. 2010. Monitoring fungicide sensitivity of Cercospora beticola of sugar beet for disease management decisions. Plant Disease 94:1272-1282.

Siah, A., Deweer, C., Morand, E., Reignault, P., and Halama, P. 2010. Azoxystrobin resistance of French Mycosphaerella graminicola strains assessed by four in vitro bioassays and by screening of G143A substitution. Crop Protection 29:737-743. 
Sierotzki, H., Frey, R., Wullschleger, J., Palermo, S., Karlin, S., Godwin, J., and Gisi, U. 2007. Cytochrome $b$ gene sequence and structure of Pyrenophora teres and P. tritici-repentis and implications for $\mathrm{Q}_{\mathrm{O}} \mathrm{I}$ resistance. Pest Management Science 63:225-233.

Sierotzki, H., Wullschleger, J., and Gisi, U. 2000. Point mutation in cytochrome $b$ gene conferring resistance to strobilurin fungicides in Erysiphe graminis f. sp. tritici field solates. Pesticide Biochemistry and Physiology 68:107-112.

Steinkamp, M. P., Martin, S. S., Hoefert, L. L., and Ruppel, E. G. 1979. Ultrastructure of lesions produced by Cercospora beticola in leaves of Beta vulgaris. Physiol. Plant Pathol 15:1326.

Stewart, C., and Via, L. E. 1993. A rapid CTAB DNA isolation technique useful for RAPD fingerprinting and other PCR applications. BioTechniques 14:748-749.

Torriani, S. F. F., Brunner, P. C., McDonald, B. A., and Sierotzki, H. 2009. QoI resistance emerged independently at least 4 times in European populations of Mycosphaerella graminicola. Pest Management Science 65:155-162.

Van den Bosch, F., Paveley, N., Shaw, M., Hobbelen, P., and Oliver, R. 2011. The dose rate debate: does the risk of fungicide resistance increase or decrease with dose? Plant Pathology 60:597-606.

Zheng, D., Olaya, G., and Köller, W. 2000. Characterization of laboratory mutants of Venturia inaequalis resistant to the strobilurin-related fungicide kresoxim-methyl. Current Genetics 38:148-155. 